\title{
IN VIVO CONFOCAL MICROENDOSCOPY: FROM THE PROXIMAL BRONCHUS DOWN TO THE PULMONARY ACINUS
}

\author{
Thiberville L., ${ }^{1,2}$ Salaün M. ${ }^{1,2}$, Bourg-Heckly G. ${ }^{3}$ \\ ' Roven University Hospital \\ 2 LITIS EA 4108 (groupe Quant-IF), Faculte' de Me'decine-Pharmacie, Roven \\ ${ }^{3}$ UMR CNRS 7033, BioMoCeTi, Universite' Pierre et Marie Curie - Paris 6, France
}

\begin{abstract}
In vivo endoscopic microscopy aims to provide the clinician with a tool to assess architecture and morphology of a living tissue in real time, with an optical resolution similar to standard histopathology. To date, available microendoscopic devices use the principle of fluorescence confocal microscopy, and thereby mainly analyse the spatial distribution of specific endogenous or exogenous fluorophores. Fluorescence microendoscopes devoted to respiratory system exploration use a bundle of optical fibres, introduced into the working channel of the bronchoscope. This miniprobe can be applied in vivo onto the bronchial inner surface or advanced into a distal bronchiole down to the acinus, to produce in situ, in vivo microscopic imaging of the respiratory tract in real time. Fluorescence confocal microendoscopy has the capability to image the epithelial and subepithelial layers of the proximal bronchial tree, as well as the more distal parts of the lungs, from the terminal bronchioles down to the alveolar ducts and sacs. Potential applications include in vivo microscopic assessment of early bronchial cancers, bronchial wall remodelling evaluation and diffuse peripheral lung disease exploration, as well as in vivo diagnosis of peripheral lung nodules. The technique has also the potential to be coupled with fluorescence molecular imaging. This chapter describes the capabilities and possible limitations of confocal microendoscopy for proximal and distal lung exploration.
\end{abstract}

Key words: bronchoscopy, confocal microscopy, in vivo microimaging, precancerous conditions, probe-based confocal laser endomicroscopy, pulmonary alveoli.

With recent advances in computer and optics engineering, diagnostic endoscopy of the respiratory tract has now entered the era of microscopic imaging $[1,2]$. Currently available microendoscopic devices use the principle of confocal fluorescence microscopy, where the microscope objective is replaced by optical fibres, which conduct both the excitation light to the tissue and the tissue fluorescence back from the fibre tip. Such systems analyse the spatial distribution of specific tissue fluorophores, or alternatively exogenous fluorophores, at the interface with the distal part of the optics. Over the last 5 yrs, fluorescence confocal microendoscopy has been successfully applied to the in vivo explorations of the gastric and colonic mucosae, the biliary tract [36] and, more recently, to the microscopic imaging of the proximal and distal respiratory systems $[7,8]$.

Translating confocal microscopy into the clinic for endomicroscopic explorations is the subject of significant scientific efforts $[9,10]$, which recently ended in the availability of commercial systems for both animal [11-13] and human in vivo explorations [5, 7, 8, 14]. To take into account the problem of both the small size and relative inaccessibility of the human respiratory system, respiratory endomicroscopic systems use the principle of fibred confocal fluorescence microscopy (FCFM) or catheter-based confocal microscopy.

\section{PRINCIPLES OF FCFM}

Confocal microscopy allows in vivo optical sectioning of cells and tissue with enhanced lateral and axial resolutions $[9,10]$, resulting in the imaging of a thin slice of a sample. The principle of confocal microscopy relies on both the use of a narrow point source on the illumination path and of a small aperture or pinhole on the light detection path. According to this principle, a laser source (the point source) focuses on a single spot in the sample and the light emitted from this focal point is imaged through the pinhole onto a detector. This results in the rejection of out-of-focus information from the material above and below a very thin plane of focus. The illumination and detection systems being conjugated on the same focal plane are termed "confocal". In order to obtain a two-dimensional image within the tissue, confocal microscopes must scan the sample in both lateral dimensions.

Respiratory confocal microendoscopes differ from the first confocal fluorescence endoscopes used for gastro-intestinal (GI) imaging by the technical approach used to scan the tissue. The Optiscan ${ }^{\circledR} /$ Pentax endomicroscope used for GI system exploration [15] uses a small scanhead ( $4.5 \mathrm{~cm}$ long, $3.5 \mathrm{~mm}$ diameter) that is included in the distal end of the endoscope. Optiscan ${ }^{\circledR}$ endomicroscopic images from the GI tract appear very close to conventional histology, with a lateral resolution below $1 \mu \mathrm{m}$ and optical slices of $7 \mu \mathrm{m}$ for a field of view of $475 \times 475 \mu \mathrm{m}$. Two drawbacks explain why this system is not yet available for respiratory tract imaging. First, because of the added sizes of the distal scanhead, working channel, conventional light guide and CCD camera, the diameter of the distal tip of the endoscope is currently larger than $12 \mathrm{~mm}$, a size barely compatib- 
le with the exploration of the human trachea and large main bronchi. Secondly, the miniaturisation of the distal scanhead results in scanning rates of 1 frame $\cdot \mathrm{s}^{-1}$, which needs a very efficient stabilisation system of the distal tip of the endoscope onto the mucosae, in order to produce crisp microscopic images of the epithelium.

To date, the only commercially available confocal endomicroscope for respiratory explorations $\left(\right.$ Cellvizio $^{\circledR}$, Mauna Kea Technologies, Paris, France), which also allows GI explorations, uses the principle of proximal scanning, in which the illumination light scans the proximal part of a coherent fibre bundle or miniprobe. This bundle conducts the light back and forth from the imaged area at the tip of the miniprobe. The light delivery, scanning, spectral filtering and imaging systems are located at the proximal part of the device, the distal part being a separate miniprobe, including both the fibre bundle and its connector to the laser scanning unit (fig. 1).

This fibre bundle based system, also described as FCFM, uses very thin and flexible miniprobes (300 $\mu \mathrm{m}-2 \mathrm{~mm}$ in diameter) that can contain up to
30,000 compacted microfibres. Similar to conventional confocal microscopes, FCFM uses two rapidly moving mirrors to scan the microfibres across the coherent fibre bundle in a raster fashion. Each microfibre, scanned one at a time by the laser light, acts as a light delivery and collection system and is, in essence, its own pinhole.

The main advantages of this design is the very small size of the probe that can reach the more distal part of the lungs, as well as the fast image collection speed that helps to avoid artefacts due to tissue movement.

Specific miniprobes for bronchial and alveolar imaging have a diameter of $1 \mathrm{~mm}$, twice the size of an alveolar duct (fig. 1). These miniprobes can enter the 2-mm working channel of adult bronchoscopes and reach any part of the lungs except the apical and posterior segments of both upper lobes, due to the relative stiffness of the probe's distal part (fig. 2) [8]. Respiratory miniprobes are devoid of distal optics and have a depth of focus of $0-50 \mu \mathrm{m}$, a lateral resolution of $3 \mu \mathrm{m}$ for a field of view of $600 \times 600 \mu \mathrm{m}$. The system produces endomicroscopic imaging in real time at 9-12 frames $\cdot \mathrm{s}^{-1}$.

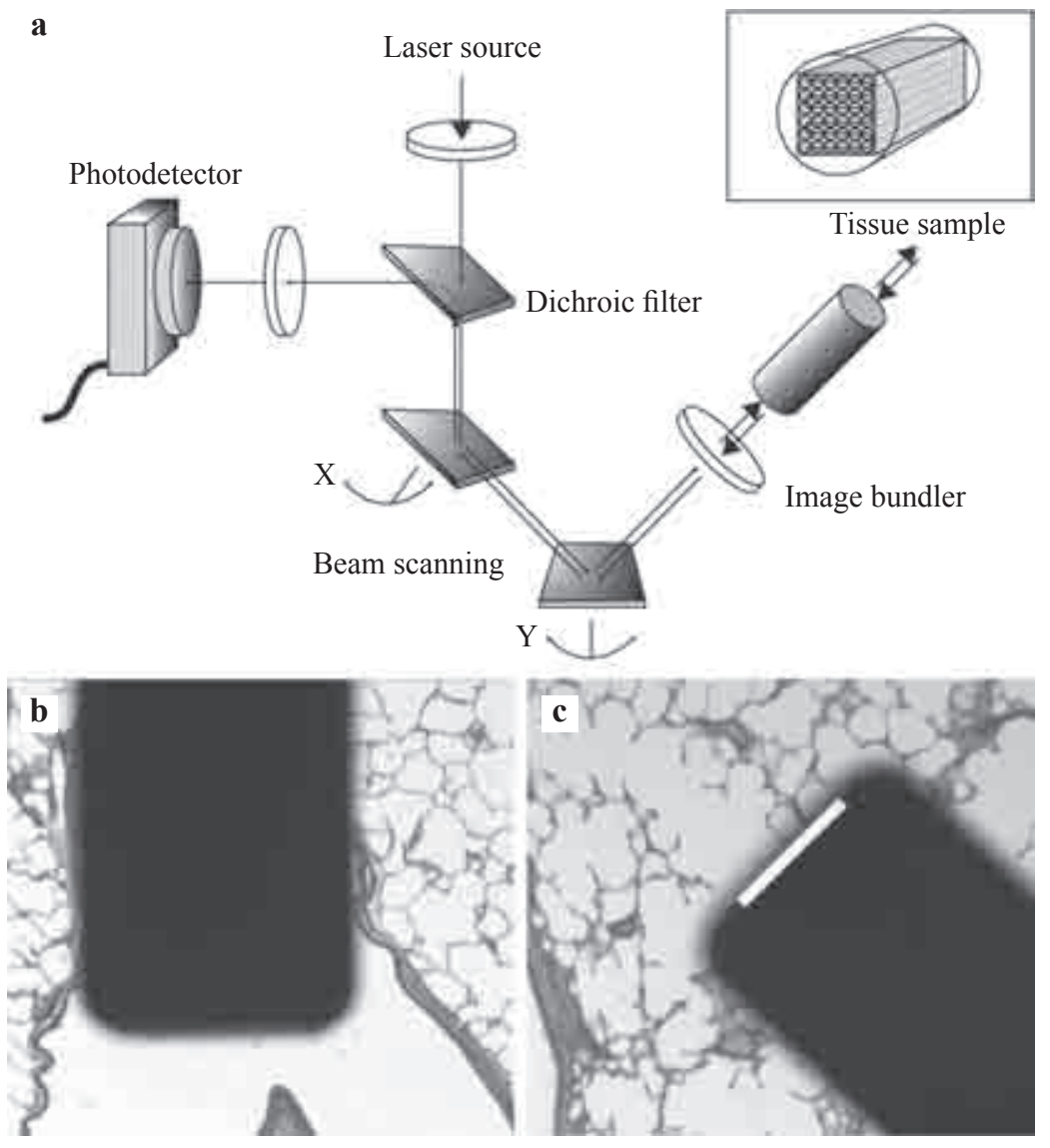

Fig. 1. - a) Schematic diagram of a fibred confocal fluorescence microscope (Cellvizio ${ }^{\circledR}$, Mauna Kea Technologies, Paris, France), and relative sizes of the 1.4-mm Alveoflex ${ }^{\circledR}$ miniprobe tip and the b) bronchiolar and c) alveolar structures. The white bar corresponds to the diameter of the fibre bundle and field of view $(600 \mu \mathrm{m})$. Reproduced from [8]

Luc Thiberville - Principal Investigator, Chef du Service Pneumologie, Rouen University Hospital, CHU de Rouen, 1 rue de Germont, 76031 Rouen Cedex, France. Dr. Mathieu Salaun - Material Sciences researcher CHU de Rouen Pneumologie. Dr. Grenevieve BourgHeckly - Clinical Research Universite Pierre et Marie Curie

For correspondence: Luc Thiberville. Clinique Pneumologique, Hospital Charles Nicolle, CHU de Rouen, 1 rue de Germont, 76031 Rouen Cedex, France. Phone +33 2328882 47. E-mail: luc.thiberville@univ-rouen.fr. 

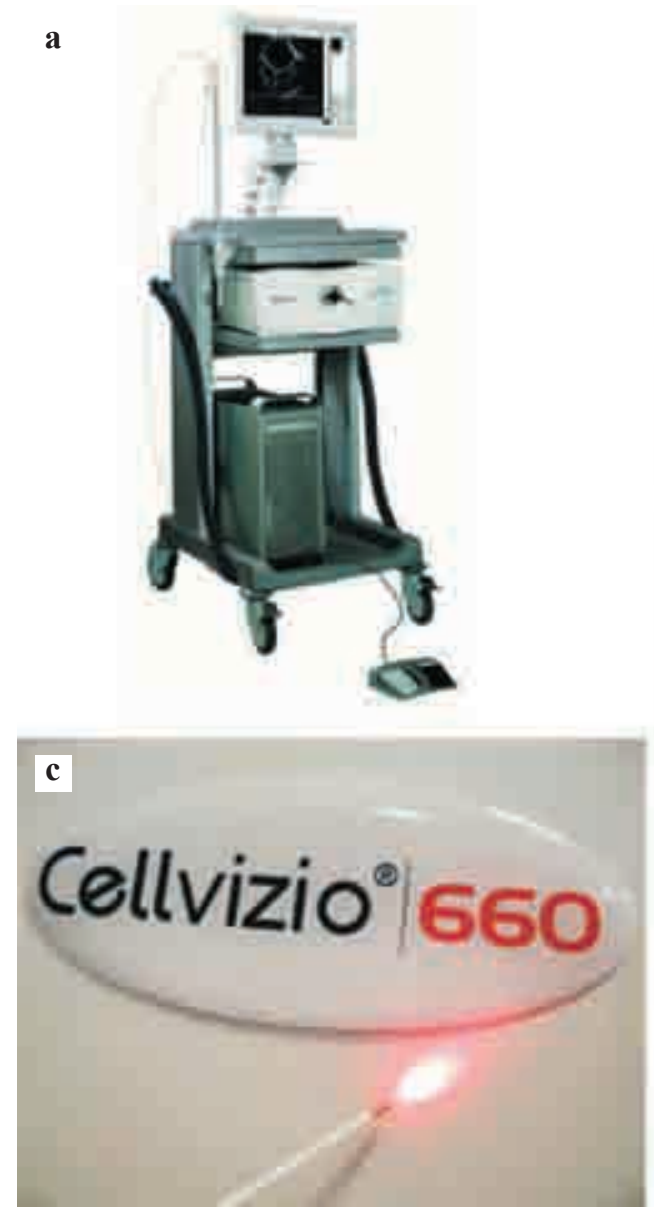
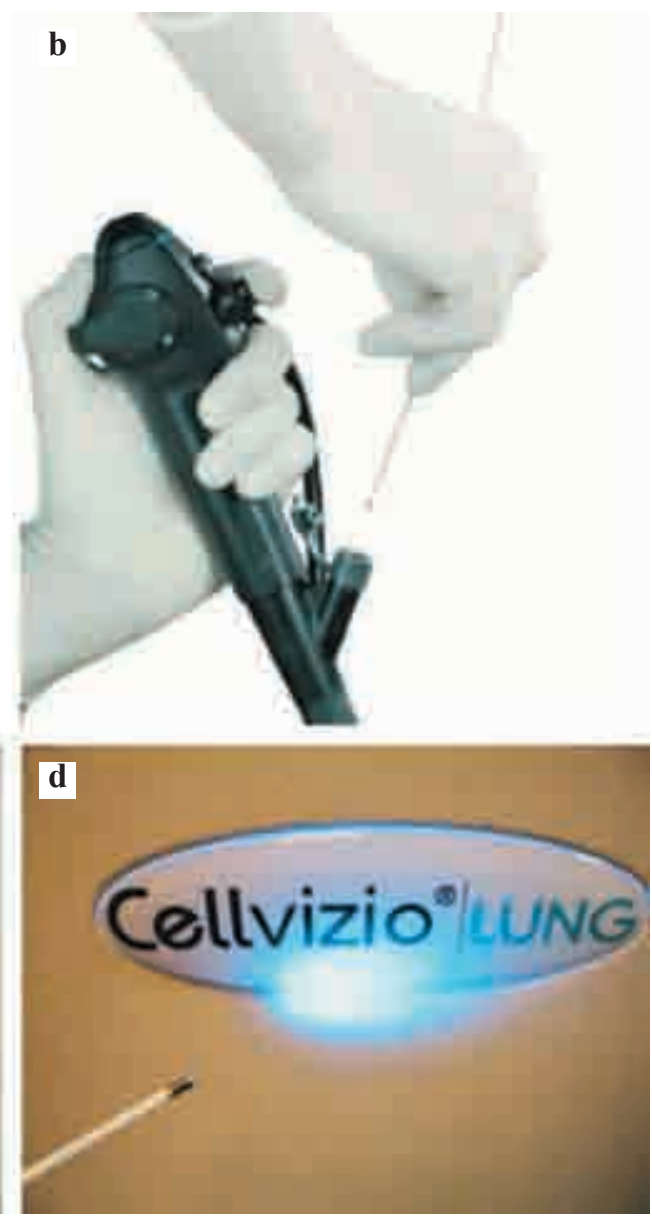

Fig. 2. - Cellvizio ${ }^{\circledR}$ systems and specifically designed miniprobes for lung exploration (Mauna Kea Technologies, Paris, France). a) Cellvizio ${ }^{\circledR}$ device, b) Alveoflex ${ }^{\circledR}$ miniprobe entering the bronchoscope working channel, c) $660 \mathrm{~nm}$ red light produced by the Cellvizio ${ }^{\circledR} 660$ device, and d) 488 nm blue light produced by the Cellvizio ${ }^{\circledR}$ lung device

Two different wavelengths are available (fig. 2). The Cellvizio ${ }^{\circledR} 488 \mathrm{~nm}$ is used for autofluorescence imaging of the respiratory tract as well as for fluorescein-induced imaging of the GI tract [6-8]. Another device at $660 \mathrm{~nm}$ excitation can be used for epithelial cell imaging after topical application of exogenous fluorophores such as methylene blue [16-18].

The main limitations of the system are related to its maximal imaging capabilities (30,000 pixels), which restrict the lateral resolution to the fibre intercore distance $(3 \mu \mathrm{m})$, and the fact that the focus point of the system cannot be adjusted. Interpretation of the data also relies on the fluorescence properties of the imaged tissue.

\section{HUMAN IN VIVO CONFOCAL MICROIMAGING OF THE NORMAL LUNG USING FCFM}

Early ex vivo experiments using fresh adult human lung samples have demonstrated that, at $488 \mathrm{~nm}$ excitation wavelength, FCFM produces a thin fibre network imaging, corresponding to the connective tissue autofluorescence of the lungs (fig. 3). This made it possib- le to conduct in vivo microscopic explorations during bronchoscopy in humans, from the proximal bronchial tree down to the most distal acinar structures of the lung.

\section{Nature of the autofluorescence bronchial and alveolar signals}

Fluorescence properties of the bronchial mucosae at $488 \mathrm{~nm}$ excitation are determined by the concentration of various cellular and extracellular fluorophores, including the intracellular flavins, that could originate from the epithelial cells, and specific crosslinks of collagens and elastin present in the subepithelial areas $[10,19,20]$. Microspectrometer experiments coupled with FCFM imaging have clearly demonstrated that the main fluorescence signal emitted after $488 \mathrm{~nm}$ excitation from both the bronchial and alveolar human system originates from the elastin component of the tissue (fig. 4) [7, 8, 21]. In contrast, the collagen fluorescence does not seem to significantly affect the FCFM image produced at $488 \mathrm{~nm}$, the fluorescence yield of collagen at this wavelength being at least one order of magnitude smaller than that of elastin. Along the same lines, flavin cellular autofluorescence appears too weak 

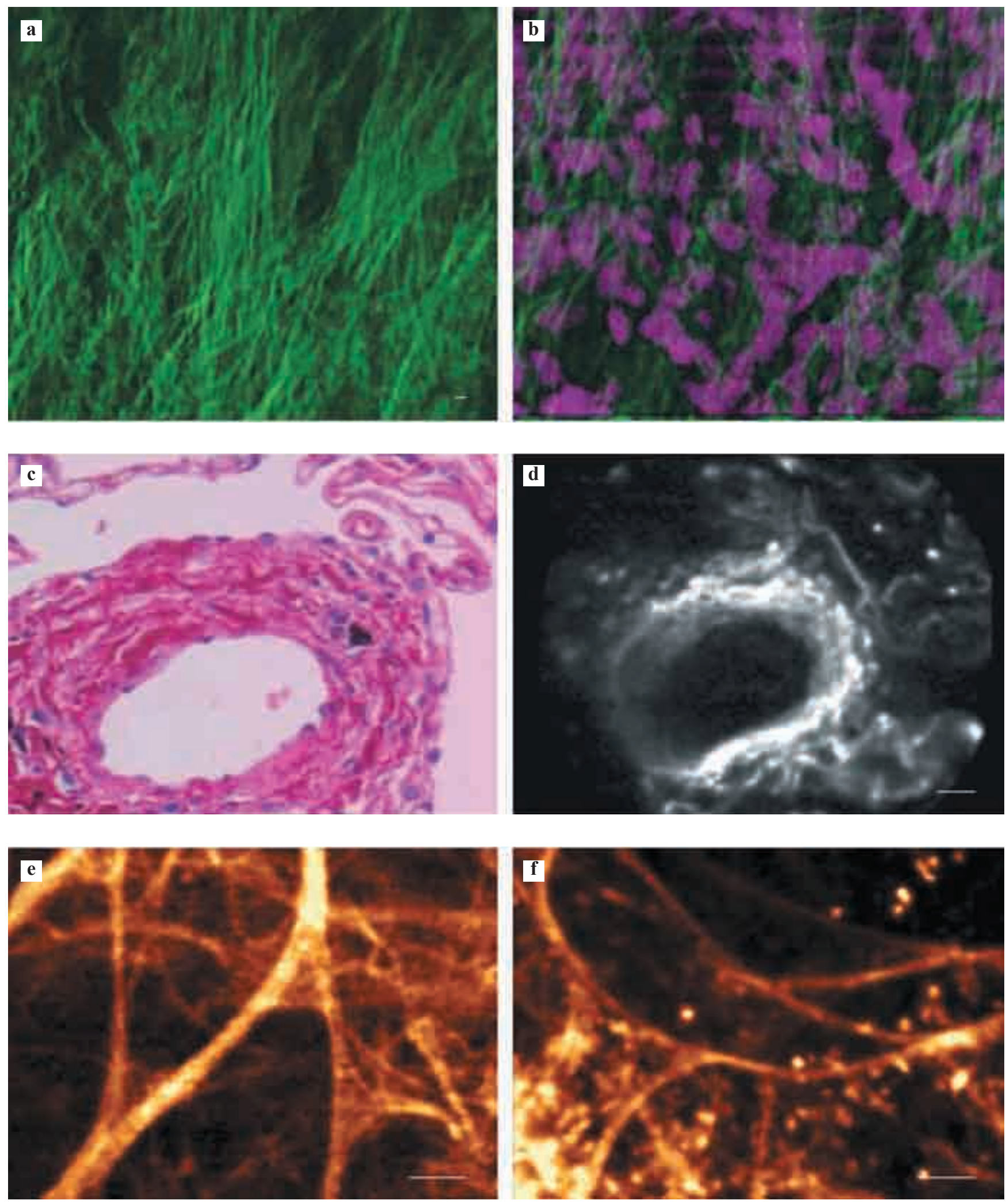

Fig. 3. - Ex vivo confocal imaging of bronchial and lung biopsies. a and b) Confocal fluorescence and reflectance imaging of fresh bronchial tissue. a) Autofluorescence images of submucosa $\sim 25-30 \mu \mathrm{m}$ below surface, $437 \mathrm{~nm}$ illumination. b) Cell nuclei reflectance and fluorescence images superimposed. c and d) Extra-alveolar vessel and adjacent alveolar walls, fixed lung section. c) Conventional histology and d) corresponding fibred confocal fluorescence microscopy (FCFM) imaging (autofluorescence, $488 \mathrm{~nm}$ illumination). e and f) Ex vivo FCFM imaging offresh parenchymal lung tissue section (488 nm illumination). e) Autofluorescence, lung elastic network and alveolar mouth imaging. f) FCFM imaging after topical application of acriflavin onto the lung section. FCFM shows fluorescent acriflavin-stained nuclei from pneumocytes, in addition to the elastin framework of the alveolar duct. Scale bars: a) $10 \mu \mathrm{m}$; d-f) $50 \mu \mathrm{m}$. a and b) Courtesy of C. MacAuley, British Columbia Cancer Research Centre, Vancouver, BC, Canada; c and d) reproduced from [8]; e and f) L. Thiberville, Rouen University Hospital, Rouen, France 

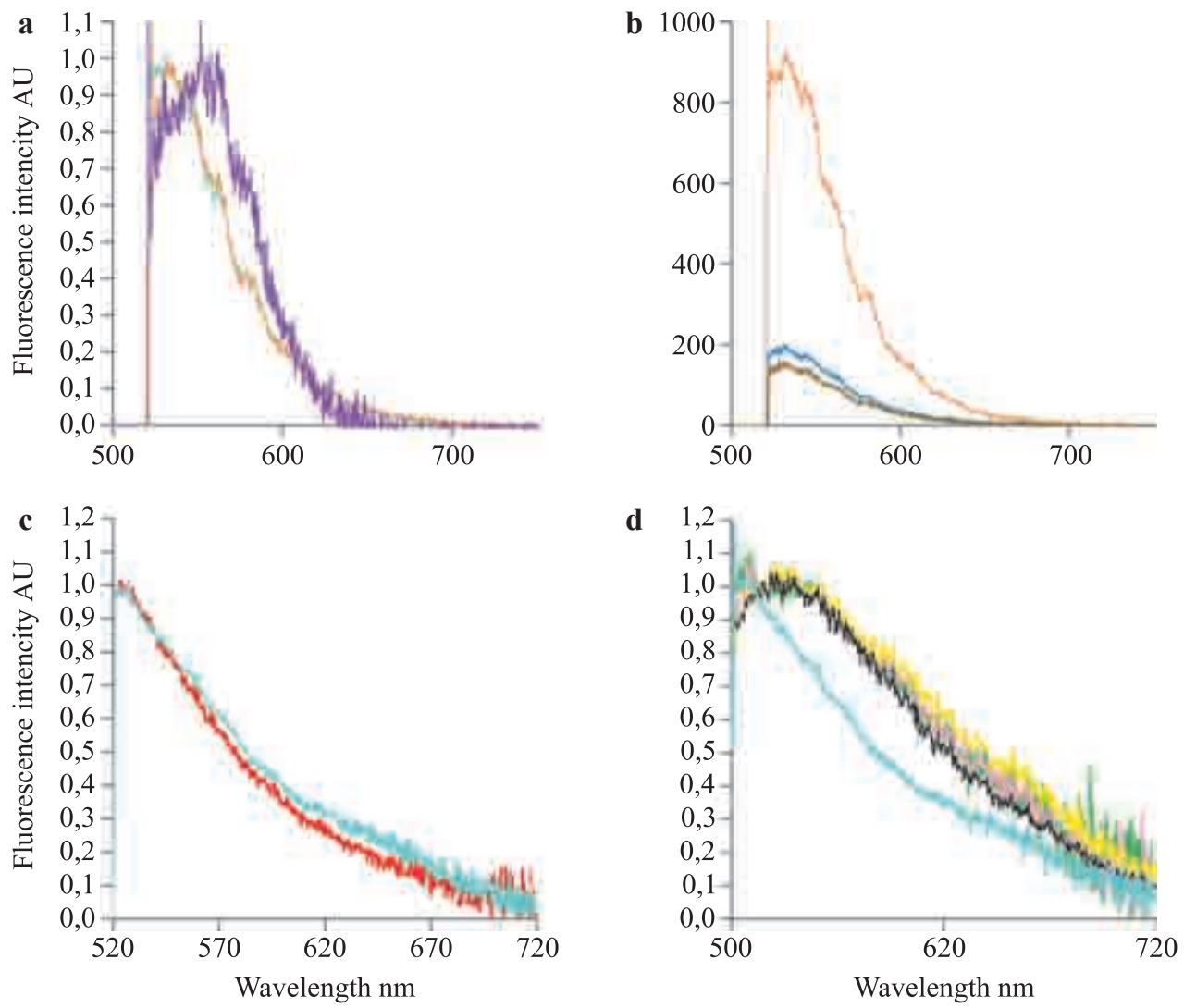

Fig. 4. - Nature of the fibred confocal fluorescence microscopy signal (autofluorescence, 488 nm illumination) in proximal bronchi and alveoli, in both smokers and nonsmoking subjects, as deduced from in vivo spectrometry experiments. a) Typical normalised autofluorescence spectra of healthy bronchial mucosa (orange), elastin powder (pale blue) and collagen (purple) excited at $488 \mathrm{~nm}$. b) Autofluorescence spectra of healthy bronchial mucosa (orange), carcinoma in situ (dark blue) and Mounier Kühn syndrome (brown) at $488 \mathrm{~nm}$ excitation. Autofluorescence emission spectra of alveolar systems from c) nonsmokers (red) and d) healthy smokers (green, pink, yellow), during in vivo alveoscopy. c and d) Pale blue: elastin powder. d) Black: smoked cigarette. AU: arbitrary units. a and b) Reproduced from [7], with permission from the publisher; c and d) reproduced from [8]

to allow imaging of the epithelial layer using $488 \mathrm{~nm}$ FCFM [22].

FCFM devices using shorter wavelength may produce slightly different imaging of the bronchial wall connective tissue (fig. 3). However, imaging the epithelial layer on top of the basement membrane network needs another approach, the accessible way being currently the use of an exogenous fluorescent dye $[18,23]$. In the future, devices based on multiple wavelengths [24], the adjunction of a reflectance device [10] or a multiphoton approach [9] may enable imaging of collagen, elastin and flavins simultaneously.

As a result, $488 \mathrm{~nm}$ excitation FCFM specifically images the elastin respiratory network that is contained in the basement membrane of the proximal airways and participates in the axial backbone of the peripheral interstitial respiratory system.

\section{In vivo autofluorescence microimaging of the proximal bronchial wall}

FCFM can easily be performed during a fibreoptic bronchoscopy under local anaesthesia $[7,8]$. The tech- nique of in vivo bronchial FCFM imaging is simple: the miniprobe is introduced into the 2-mm working channel of the bronchoscope and the probe tip applied onto the bronchial mucosae under sight control. The depth of focus being $50 \mu \mathrm{m}$ below the contact surface, the system can image the first layers of the bronchial subepithelial connective tissue, presumably the lamina densa and the lamina reticularis [7].

At $488 \mathrm{~nm}$ excitation, FCFM produces very precise microscopic fluorescent images of the bronchial basement membrane zone. As seen in figure 5 , in vivo FCFM bronchial microimaging reveals a mat of large fibres mainly oriented along the longitudinal axis of the airways with crosslinked smaller fibres, as well as larger openings $(100-200 \mu \mathrm{m})$ corresponding to the bronchial gland origins. In vivo, the technique also makes it possible to record high-resolution images of small airways such as terminal bronchioles, which are recognisable by the presence of the helicoidal imprint of the smooth muscle on the inner part of the bronchiole (fig. 5) [7].

Application of the FCFM imaging system for the exploration of proximal bronchial diseases is still at its 

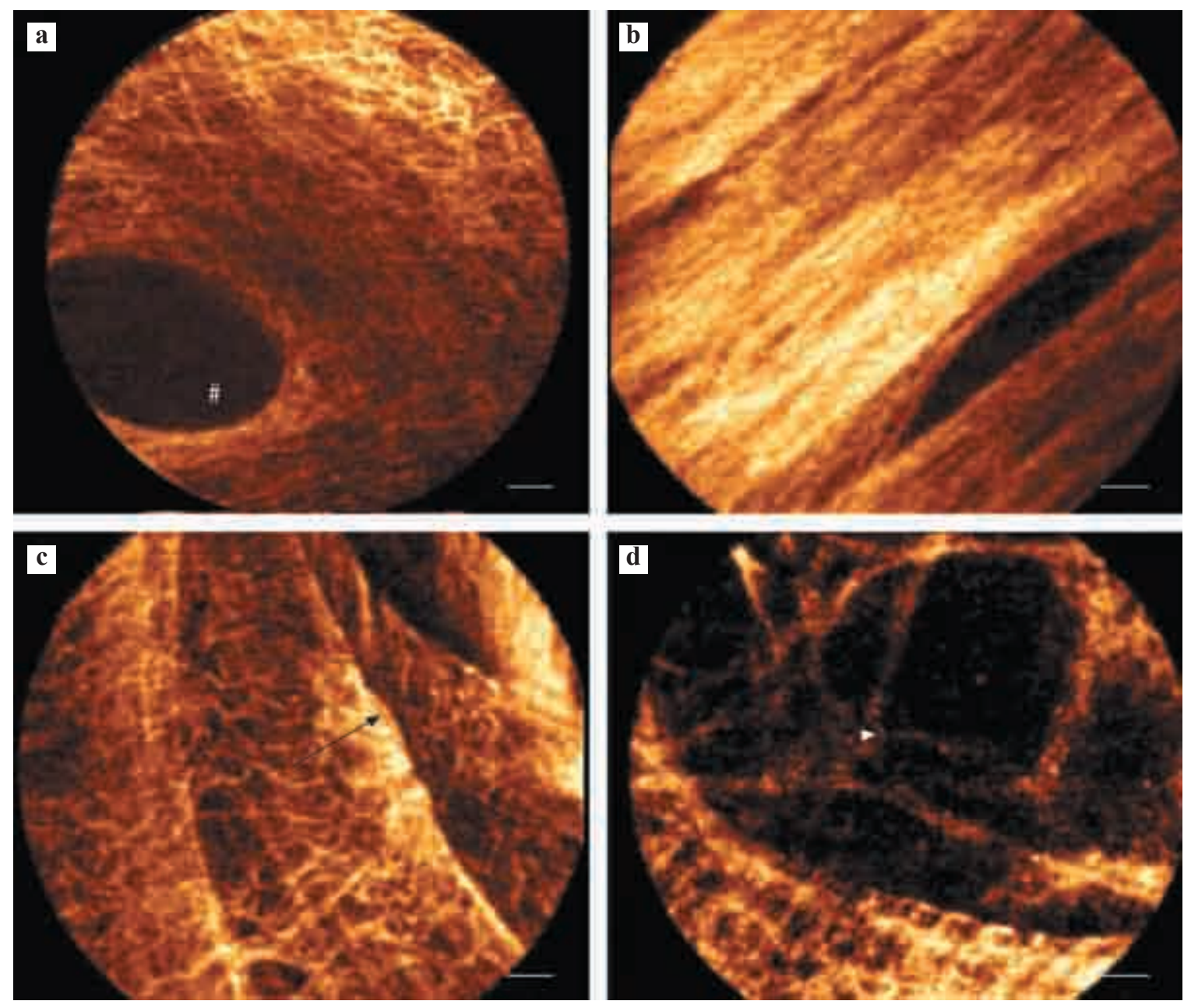

Fig. 5. - In vivo fibred confocal fluorescence microscopy imaging of human bronchi and bronchioles. a) Proximal bronchus, opening of a bronchial gland (\#). b) Main bronchus, elastic fibred network oriented along the longitudinal axis of the airways. c) Distal bronchiole showing helicoidal imprints of smooth muscles (arrow). d) Transitional bronchiole showing an alveolar bud (arrowhead). Scale bars: $50 \mu \mathrm{m}$

beginning, with early results being published on bronchial wall remodelling in benign [7] and preinvasive bronchial lesions $[7,18]$.

\section{In vivo assessment of bronchial wall remodelling}

FCFM imaging of the bronchial wall microstructure underlying premalignant epithelia is significantly modified [7]. In these precancerous conditions, the elastic fibred pattern of the lamina reticularis disappears in most cases, while appearing disorganised in about onethird of the lesions, supporting the hypothesis of an early degradation of the basement membrane components in preinvasive bronchial lesions (fig. 6) [7]. Whether early remodelling of the lamina reticularis is associated with specific outcomes of the lesions should be further explored.

However, while this observation shed some light on the origin of the autofluorescence defect in precancerous bronchial lesions, the absence of epithelial cell visualisation in this study did not allow the technique to differentiate between the different grades of progression of the precancerous bronchial lesions such as metaplasia/dysplasia/ carcinoma in situ (see section on FCFM assessment of the bronchial epithelial cell layer, and figure 6).

Besides the study of the premalignant bronchial wall alterations, the application of FCFM could be extended to the field of nonmalignant bronchial diseases. In one study, a complete disappearance of the bronchial wall fibred connective network was observed in a tracheomegaly syndrome, a pathological condition related to a defect in elastic component of the bronchial wall [7]. The same study also observed a remarkable FCFM aspect in a case of sarcoidosis, corresponding to subepithelial granuloma upon bronchial sampling. Whereas still limited, these observations indicate that per endoscopic FCFM could be used to study specific basement membrane remodelling alterations such as in chronic bronchial inflammations, asthma and chronic obstructive pulmonary disease. 

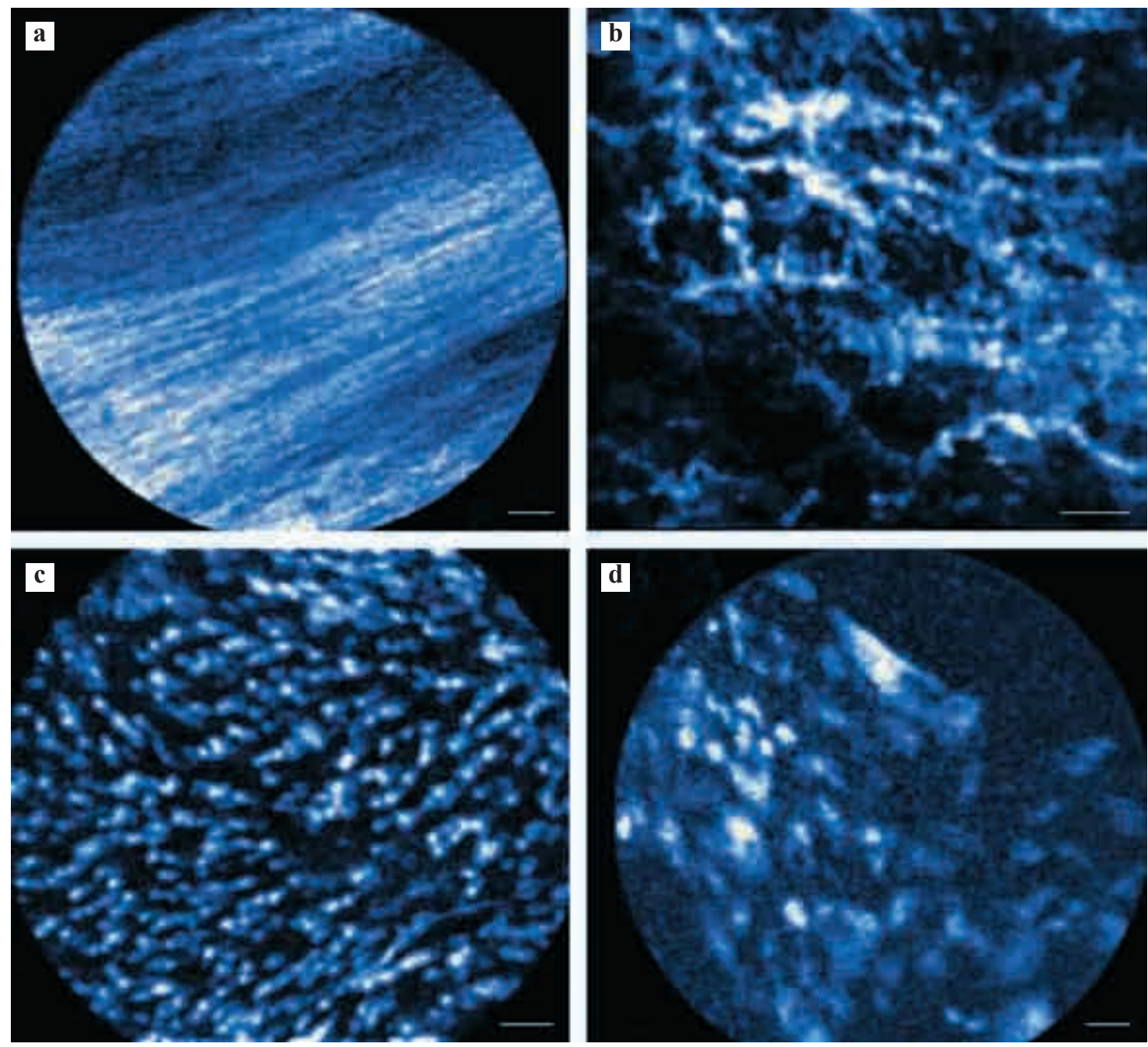

Fig. 6. - Epithelial and subepithelial confocal microendoscopy imaging of normal and precancerous lesions. a) Normal elastic fibred network of the basement membrane zone. b) Disorganised basement membrane zone elastic network at the vicinity of a bronchial carcinoma in situ (CIS). c) Regular normal bronchial epithelium and d) CIS. a and b) Images taken at $488 \mathrm{~nm}$ excitation without exogenous fluorophore (Cellvizio $\left.{ }^{\circledR} 488\right)$. Under these conditions, only the elastin of the basement membrane is detectable and imaged. $\mathrm{c}$ and d) Taken at $660 \mathrm{~nm}$ excitation using topical methylene blue (0.1\%), in order to image the epithelial layer (Cellvizio ${ }^{\circledR}$ 660). All images were recorded in vivo during bronchoscopy, but with two different laser scanning units (Cellvizio $^{\circledR} 488$ and 660; Mauna Kea Technologies, Paris, France). Scale bars: a, c, d) $50 \mu$ m; b) $40 \mu \mathrm{m}$. Source: L. Thiberville, Rouen University Hospital, Rouen, France

\section{FCFM ASSESSMENT OF THE BRONCHIAL EPITHELIAL CELL LAYER}

In order to be successfully applied to the exploration of precancerous/cancerous bronchial epithelium, the FCFM technique would need to be coupled with the use of an exogenous nontoxic fluorophore. Ex vivo studies have shown that the resolution of the system is not a limitation for nuclear or cellular imaging [7, 8]. Exogenous fluorophores that could be activated at $488 \mathrm{~nm}$, such as acriflavin (a putative mutagen agent) or fluorescein solution, which does not stain the nuclei [25], are not approved for intrabronchial use. Recently, Lane et al. [23] have used a confocal microendoscope prototype at $488 \mathrm{~nm}$ excitation and topical physiological $\mathrm{pH}$ cresyl violet to provide cellular contrast in the bronchial epithelium both in vitro and in vivo.
Methylene blue is a nontoxic agent which is commonly used during bronchoscopy for the diagnostic of bronchopleural fistulae. It is also used in gastroenterology for chromo-endoscopic detection of precancerous lesions [26-28], as well as for in vivo microscopic examination of the GI tract and bronchus using a novel endocytoscopic system $[29,30]$. Methylene blue is a potent fluorophore that enters the nuclei and reversibly binds to the DNA, before being reabsorbed by the lymphatics. In order to give a fluorescent signal, methylene blue needs to be excited around $660 \mathrm{~nm}$, and is therefore accessible to FCFM intravital imaging using this excitation wavelength.

Preliminary study has demonstrated that Cellvizio ${ }^{\circledR}$ 660/topical methylene blue makes it possible to reproducibly image the epithelial layer of the main bronchi (fig. 6) [18]. Future studies using this technique could make it possible to differentiate normal, premalignant 
and malignant alterations at the microscopic level in vivo. If this strategy is successful, FCFM may become a very powerful technique for in vivo diagnosis of early malignant and premalignant conditions of the bronchial tree, allowing the analysis of both the epithelial and subepithelial layers during the same procedure.

\section{DISTAL AND TRANSITIONAL BRONCHIAL IMAGING}

When progressing towards the more distal parts of the bronchial tree, small noncartilaginous bronchioles are easily recognisable because of the helicoidal imprint of the smooth muscles on the bronchiolar walls (fig. 5). However, the orthogonal branching and the small calibre of the terminal and respiratory bronchioles in humans compared with the probe size implies that the progression of the probe towards the acinus regularly bypasses the transitional respiratory bronchioles. While FCFM images of alveolar buds in respiratory bronchio- les could be observed casually (fig. 5) [8], FCFM study of the distal membranous and respiratory bronchioles appears difficult, unless thinner probes, currently devoted to experimental animal imaging, become clinically available in the future [13].

\section{FCFM IMAGING OF THE ACINUS AND PERIPHERAL CONNECTIVE TISSUE NETWORK}

Earlier work has demonstrated that elastin represents up to $50 \%$ of the peripheral lung connective tissue fibres [31]. Following the first work on the proximal bronchi, FCFM rapidly appeared to be able to image the elastic framework of the distal lung as well [8]. In the acinus, elastin is present in the axial backbone of the alveolar ducts and alveolar entrances, as well as in the external sheath of the extra-alveolar microvessels $[32,33]$, explaining the nature of the intra-acinar FCFM imaging (figs 3 and 7).
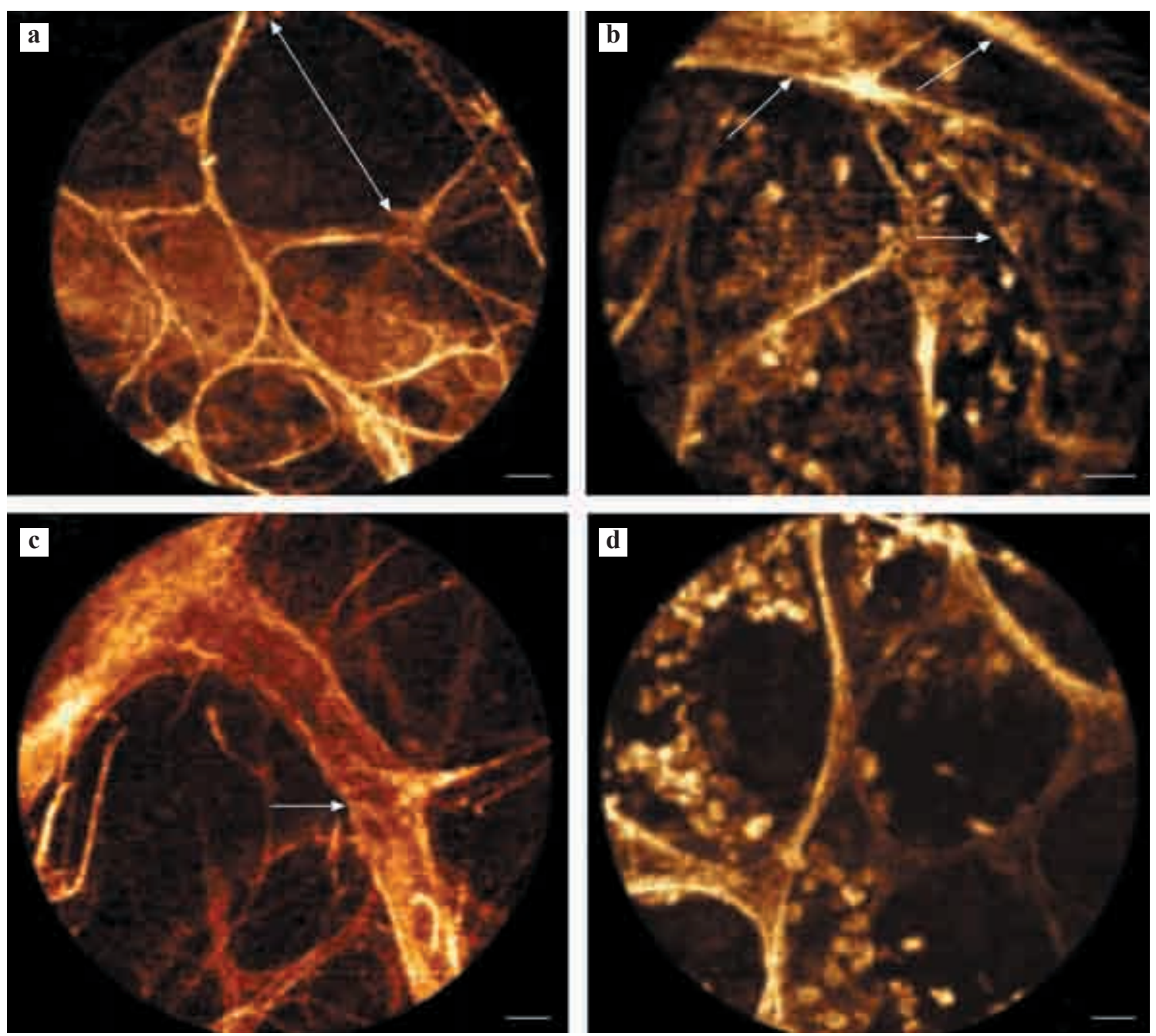

Fig. 7. - In vivo fibred confocal fluorescence microscopy (FCFM) imaging during alveoscopy, 488 nm illumination. a and c) Nonsmoking subject. Elastin framework of a) an alveolar mouth (diameter $267.7 \mu \mathrm{m}$ (double arrow)) and c) extra-alveolar microvessel (arrow). b and d) FCFM imaging of smoker alveoli, showing alveolar walls, edge of an alveolar duct (arrows) and alveolar macrophages. Scale bars: $50 \mu \mathrm{m}$ 
For distal lung microimaging, the use of a small bronchoscope with a 2-mm working channel appears useful in order to more efficiently orientate the probes into the regions of interest. The FCFM miniprobe is then gently advanced into the distal bronchiole until the alveolar system is observed. During the procedure, several acinar areas can be successively explored by selecting different bronchioles, with real-time imaging. Once the alveoli are reached, the probe is slightly pulled back until the contact is lost, to ensure that the probe compression effect onto the alveolar system is minimal.

Experience of in vivo FCFM alveolar imaging has demonstrated that the technique is very well tolerated under topical anaesthesia in spontaneously breathing awake subjects. Due to the lack of pain receptors in the bronchial tree down to the subpleural level, the penetration of the miniprobe into the pulmonary lobule through the distal bronchiolar wall is painless [8]. In addition, acinar imaging is not associated with significant bleeding in the proximal airways, in contrast to what is usually observed with transbronchial biopsy sampling. This is explained by the low pressure in the alveolar capillaries that could be altered during the progression of the probe, as well as by the smooth design of the probe tip that can displace the extra-alveolar microvessels without damage. No pleural complication occurred in our experience in more than 150 patients and healthy volunteers, despite multiple lung segment imaging during the endoscopy, when the system is used in awake, spontaneously breathing subjects.

\section{ACINAR FCFM IMAGING IN NONSMOKING SUBJECTS}

Acinar imaging is easily obtained by pushing forward the probe a few centimetres after the endoscope is distally blocked into a subsegmental bronchus. Due to the respective sizes of the probe tip and of the distal bronchiolar structures, the entry into the alveolar space is obtained by penetration through the thin wall of a small distal bronchiole.

In nonsmokers, FCFM mainly produces images of the elastic fibres that encircle the alveolar openings, reinforce the virtual wall ofthe alveolar ducts and surround the extra-alveolar microvessels (fig. 7).

The in vivo aspects of this distal elastic framework may vary depending on the angle of penetration of the probe into the alveolar unit. A direct view down the axis of the duct or an oblique view could be commonly obtained, from which the "helical" or "looped" shape of the duct's elastic structure could be easily recognised (fig. 7) [8].

The reproducibility of the technique has been demonstrated in a series of healthy volunteers, where alveolar opening sizes measured from in vivo imaging were found normally distributed with mean values (around $275 \mu \mathrm{m}$ ) close to what is observed using complex stereological methods in vitro [32,33], with thickness of the elastic fibres being $10 \pm 2.7 \mu \mathrm{m}$ (table 1 and fig. 8) [8]. In the published series, smaller alveolar mouths were observed in the right upper lobe and paracardiac segments, presumably in relation to the lower ventilation of these segments in supine position [8]. The technique also enables precise measurements of the extra-alveolar lobular microvessels.

Interestingly, significant variation in the intensity of the autofluorescence signal could be observed between the subjects, the oldest individuals presenting the strongest signal, indicating structural modifications of lung elastin crosslinks in relation to ageing.

\section{ACINAR AND ALVEOLAR IMAGING IN ACTIVE SMOKERS}

Alveolar fluorescence imaging in active smokers dramatically differs from imaging in nonsmo-

Table 1

In vivo alveolar endoscopy in smoking and nonsmoking healthy volunteers

\begin{tabular}{|l|c|c|c|}
\hline & Smokers & Nonsmokers & All subjects \\
\hline Subjects & 17 & 24 & 41 \\
\hline Age yrs & $37 \pm 16$ & $46 \pm 13$ & $42 \pm 15$ (range 21-62) \\
\hline Duration of alveolar procedure min & $14 \pm 6$ & $10 \pm 3$ & $11 \pm 5$ \\
\hline Alveolar mouth diameter $\mu \mathrm{m}$ & $274 \pm 52$ & $283 \pm 54$ & $278 \pm 53$ \\
\hline$\quad$ Measurements & 149 & 125 & 274 \\
\hline Elastic fibre thickness $\mu \mathrm{m}$ & $9.70 \pm 3.0$ & $10.38 \pm 2.34$ & $10.05 \pm 2.71$ \\
\hline$\quad$ Measurements & 445 & 464 & 909 \\
\hline Microvessel diameter $\mu \mathrm{m}$ & $95 \pm 47$ & $89 \pm 56$ & $90 \pm 50$ \\
\hline$\quad$ Measurements & 79 & 171 & 250 \\
\hline Subjects with alveolar fluorescent macrophages & $16^{\#}$ & $1^{\#}$ & 17 \\
\hline Alveoli with fluorescent macrophages/total alveoli & $77 / 85^{\#}$ & $1 / 107^{\#}$ & $78 / 192$ \\
\hline
\end{tabular}

Data are presented as $\mathrm{n}$ or mean $\pm \mathrm{SD}$, with the exception of microvessel diameter, which is presented as median \pm interquartile range. ${ }^{\#}: \mathrm{p}<0.0001$, Chi-squared test. Adapted from [8]. 


$$
\text { a }
$$
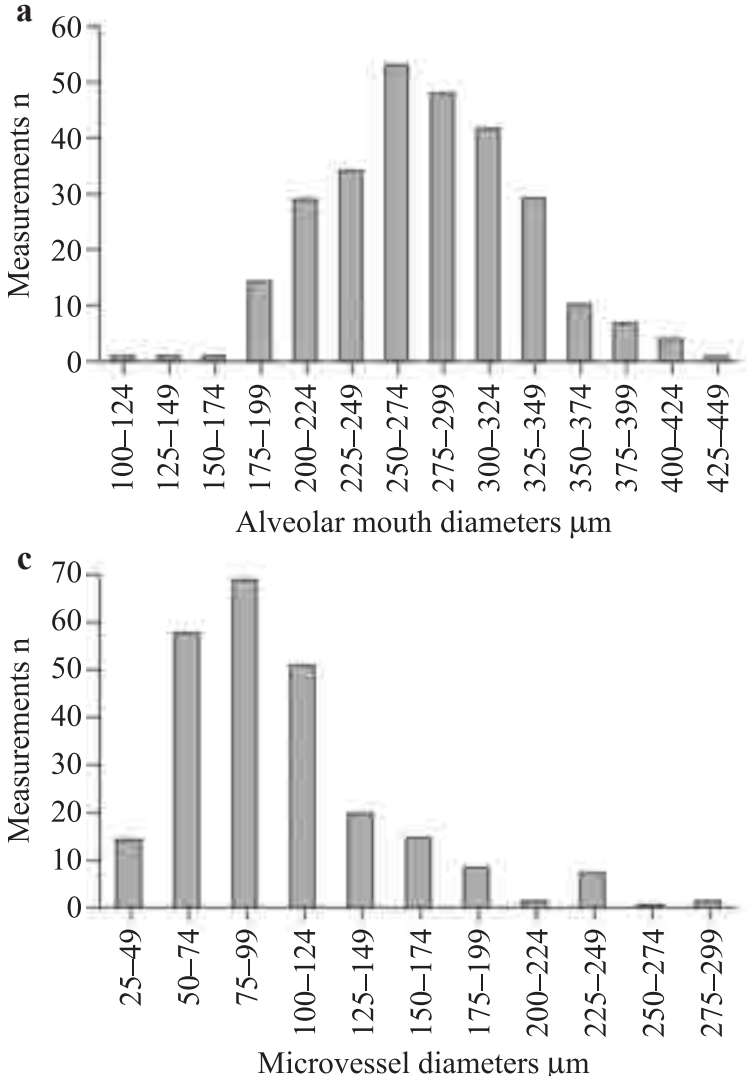

b

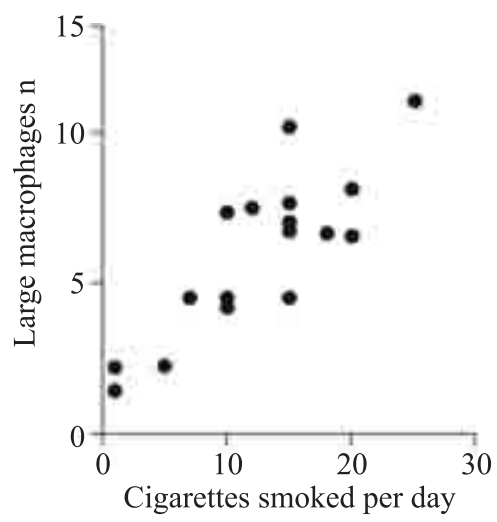

d

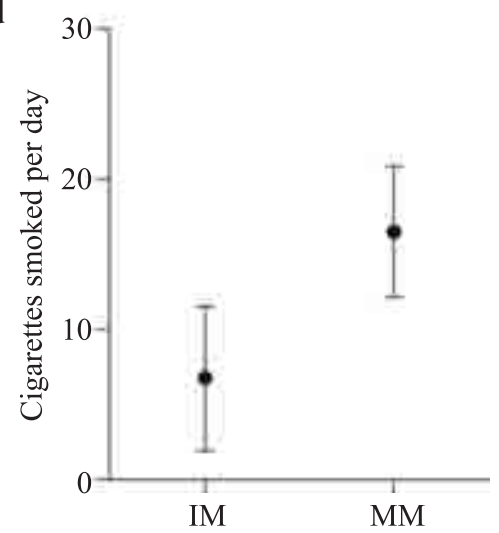

Fig. 8. - In vivo intra-acinar morphometric and cellular assessment using fibred confocal fluorescence microscopy. a and c) Distribution of alveolar mouth and extra-alveolar microvessel diameters in a series of healthy volunteers explored with alveoscopy. b and d) In vivo assessment of alveolar macrophage size and mobility according to tobacco exposure. b) Large macrophages were $>30 \mu \mathrm{m}$. $\mathrm{r}=0.77, \mathrm{p}<0.0002$. d) IM: immobile macrophages; MM: mobile macrophages. $\mathrm{p}<0.0001$. Modified from [8]

kers (fig. 7). The alveolar areas of smokers are usually filled with highly fluorescent cells corresponding to alveolar fluorescent macrophages, the presence of which appears very specific to active smoking. Using FCFM, morphological markers of alveolar macrophage activation such as size, number and mobility can be assessed, which appear highly correlatedwiththeamountofcigarettessmokedper day (fig. 8) [8].

The alveolar autofluorescence intensity appears significantly higher in active smokers compared with nonsmokers, in relation to the intensity of the macrophage alveolitis. In situ alveolar microspectrometric measurements have been performed in active smokers, which showed that the main fluorophore contributing to the FCFM alveolar signal corresponds to the tobacco tar by itself, explaining this difference (fig. 4) $[8,21]$. Due to this specific contrast imaging in smokers, details of the alveolar and ductal surface could often be obtained (fig. 7).

\section{POTENTIAL APPLICATIONS AND POSSIBLE LIMITATIONS OF FCFM FOR DISTAL LUNG IMAGING}

The broncho-alveoscopy procedure is the first technique that makes it possible to obtain real-time, high- resolution, microstructural images of lobular and alveolar lung structures in living humans. As such, the technique appears to have a great potential for in vivo, minimally invasive exploration of the distal lung. For distal lung imaging, the technique could also be coupled with modern techniques of distal structure localisation and sampling, such as with electromagnetic navigation or miniprobe-based radial endobronchial ultrasound. FCFM clinical applications with the greatest potential are the assessment of diffuse peripheral lung diseases and in vivo diagnosis of peripheral lung nodules [17].

Typical alterations of the elastic framework in a case of idiopathic pulmonary fibrosis and cellular imaging of a peripheral adenocarcinoma are shown in figure 9.

Whereas preliminary FCFM results in both these directions appear very encouraging, potential difficulties of the technique should be underlined. These difficulties are mainly related to the interpretation of the FCFM images and standardisation of the alveolar imaging.

Altered FCFM images of the acinar elastic network may be encountered in normal human lung, related to the compression and alterations of the fragile acinar framework during the progression of the probe. This is due to the mode of penetration of the probe into the acinus, which supposes the disruption of bronchiolar and 

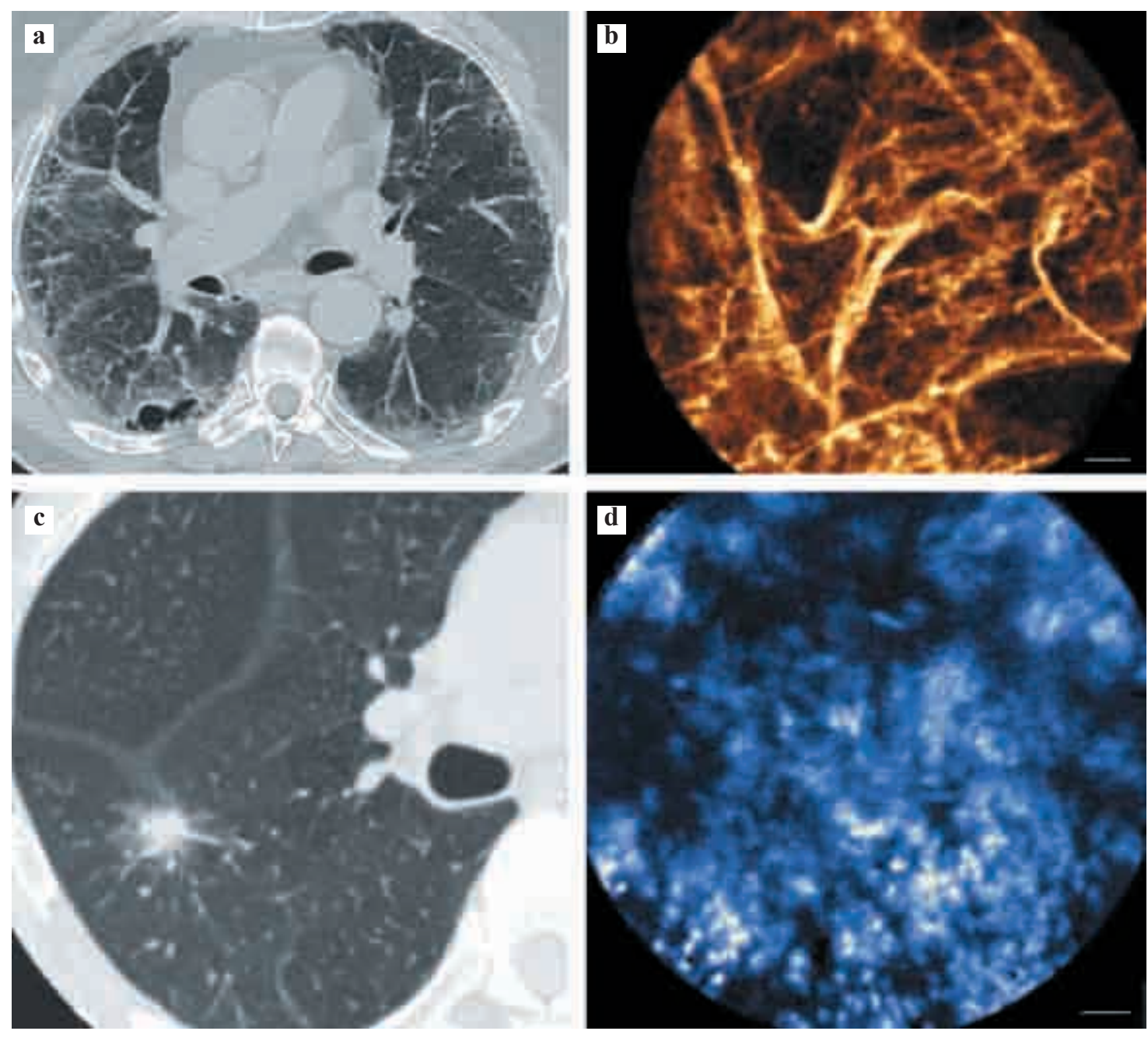

Fig. 9. - Fibred confocal fluorescence microscopy (FCFM) imaging of the peripheral lung. a and b) Idiopathic pulmonary fibrosis. c and d) Peripheral lung nodule: adenocarcinoma. a and c) Chest computed tomography scan. b) Distal FCFM imaging in the lingula (LB5a) (autofluorescence FCFM at $488 \mathrm{~nm}$ ). d) FCFM imaging of the peripheral nodule represented in (c). The confocal miniprobe has been introduced in the nodule using radial endobronchial ultrasound through the external sheath, before sampling (topical methylene blue and $660 \mathrm{~nm}$ FCFM). Scale bars: $50 \mu \mathrm{m}$

alveolar walls, followed by a compression effect on the more resistant ductal structures. Minimal imaging distortion is observed when the probe is applied on the axis of the duct, resulting in the visualisation of more details in the background planes than theoretically allowed by the $50 \mu \mathrm{m}$ depth of focus of the system [13]. This compression effect may be difficult to control in vivo. In our hands, the more reproducible results are obtained by gently pulling back the probe once the alveolar imaging is obtained and analysing the last images before the contact is lost. Therefore, future studies should include a standardisation of the endoscopic technique.

Conversely, FCFM exclusively records the signal coming from fluorescent structures in response to appropriate excitation wavelengths. In this regard, in its autofluorescence mode (i.e. without the use of exogenous fluorophore), in vivo FCFM in nonsmokers only images the elastin of the peripheral and axial connective tissues. Data from the literature indicate that such information might be helpful for the exploration of several peripheral lung diseases [34-36]. However, as the confocal fluorescence imaging of the distal lung is likely to appear very different from the corresponding histopathology, the semiology of the FCFM elastin lung network imaging will have to be characterised in pathological conditions. In this regard, in vivo comparative studies on confocal alveolar imaging in patients with peripheral lung diseases and healthy volunteers appear mandatory, before the place of FCFM in the routine exploration of the peripheral lung can be appreciated.

Until now, confocal microendoscopy of the airways has only used endogenous autofluorescence or simple fluorescent contrast agents to visualise the in vivo cellular and interstitial organisation of the airways and distal lung parenchyma. In the future, using molecular contrast compounds, it will be possible to extend the applications of the technique to the area of in vivo molecular imaging. Pilot studies exploring this strategy have recently been published that provided specific confocal imaging of molecular probes in precancerous 
conditions of the oral cavity ex vivo [37] and of colonic dysplasia in vivo [38]. Coupled to FCFM, molecular imaging may help in the future to enable early diagnosis, rapid typing of molecular markers and assessment of therapeutic outcome in many lung diseases.

\section{REFERENCES}

1. Kiesslich R., Goetz M., Neurath M.F. Virtual histology // Best Pract Res Clin Gastroenterol. 2008; 22: 883-897.

2. Guillaud M., Richards-Kortum R., Follen M. Paradigm shift: a new breed of pathologist // Gynecol. Oncol. 2007; 107: Suppl. 1, S46-S49.

3. Goetz M., Kiesslich R. Confocal endomicroscopy: in vivo diagnosis of neoplastic lesions of the gastrointestinal tract // Anticancer Res. 2008; 28: 353-360.

4. Goetz M., Kiesslich R., Dienes H.P., Drebber U., Murr E., Hoffman A., Kanzler S., Galle P.R., Delaney P., Neurath M.F. In vivo confocal laser endomicroscopy of the human liver: a novel method for assessing liver microarchitecture in real time // Endoscopy. 2008; 40: 554-562.

5. Kiesslich R., Goetz M., Neurath M.F. Confocal laser endomicroscopy for gastrointestinal diseases // Gastrointest. Endosc. Clin. N Am. 2008; 18: 451-466.

6. Meining $A$. Confocal endomicroscopy // Gastrointest. Endosc. Clin. N Am. 2009; 19: 629-635.

7. Thiberville L., Moreno-Swirc S., Vercauteren T., Peltier E., Cavé C., Bourg Heckly G. In vivo imaging of the bronchial wall microstructure using fibered confocal fluorescence microscopy // Am. J. Respir. Crit. Care Med. 2007; 175: 22-31.

8. Thiberville L., Salaün M., Lachkar S., Dominique S., Moreno-Swirc S., Vever-Bizet C., Bourg-Heckly G. Human in vivo fluorescence microimaging of the alveolar ducts and sacs during bronchoscopy // Eur. Respir. J. 2009; 33: 974-985.

9. St Croix C.M., Leelavanichkul K., Watkins S.C. Intravital fluorescence microscopy in pulmonary research // Adv. Drug. Deliv. Rev. 2006; 58: 834-840.

10. MacAulay C., Lane P., Richards-Kortum R. In vivo pathology: microendoscopy as a new endoscopic imaging modality // Gastrointest. Endosc. Clin. N Am. 2004; 14: 595-620.

11. Boyette L.B., Reardon M.A., Mirelman A.J., Kirkley T.D., Lysiak J.J., Tuttle J.B., Steers W.D. Fiberoptic imaging of cavernous nerves in vivo // J. Urol. 2007; 178: 2694 2700 .

12. Laemmel E., Genet M., Le Goualher G., Perchant A., Le Gargasson J.F., Vicaut E. Fibered confocal fluorescence microscopy (CellviZio) facilitates extended imaging in the field of microcirculation. A comparison with intravital microscopy // J. Vasc. Res. 2004; 41: 400-411.

13. Vincent P., Maskos U., Charvet I., Bourgeais L., Stoppini L., Leresche N., Changeux J.P., Lambert R., Meda P., Paupardin-Tritsch $D$. Live imaging of neural structure and function by fibred fluorescence microscopy // EMBO Rep. 2006; 7: 1154-1161.

14. Hoffman A., Goetz M., Vieth M., Galle P.R., Neurath M.F., Kiesslich R. Confocal laser endomicroscopy: technical status and current indications // Endoscopy. 2006; 38: 1275-1283.

15. Kiesslich R., Goetz M., Vieth M., Galle P.R., Neurath M.F. Confocal laser endomicroscopy // Gastrointest. Endosc. Clin. N Am. 2005; 15: 715-731.

16. Peng Q., Brown S.B., Moan J., Nesland J.M., Wainwright M., Griffiths J., Dixon B., Cruse-Sawyer J., Vernon $D$. Biodistribution of a methylene blue derivative in tumor and normal tissues of rats // J. Photochem. Photobiol. B. 1993; 20: 63-71.

17. Thiberville L., Salaün M., Lachkar S., Dominique S., Moreno-Swirc S., Vever-Bizet C., Bourg-Heckly G. In vivo confocal endomicroscopy of peripheral lung nodules using $488 \mathrm{~nm} / 660 \mathrm{~nm}$ induced fluorescence and topical methylene blue // Eur. Respir. J. 2008; 32: Suppl. 52, $263 \mathrm{~s}$.

18. Thiberville L., Salaün M., Moreno-Swirc S. In vivo endoscopic microimaging of the bronchial epithelial layer using $660 \mathrm{~nm}$ fibered confocal fluorescence microscopy and topical methylene blue // Eur. Respir. J. 2007; 30: Suppl. 51, 712s.

19. Gabrecht T., Andrejevic-Blant S., Wagnieres G. Blue-violet excited autofluorescence spectroscopy and imaging of normal and cancerous human bronchial tissue after formalin fixation // Photochem. Photobiol. 2007; 83: 450-458.

20. Richards-Kortum R., Sevick-Muraca E. Quantitative optical spectroscopy for tissue diagnosis // Annu Rev. Phys. Chem. 1996; 47: 555-606.

21. Bourg-Heckly G., Thiberville L., Vever-Bizet C. In vivo endoscopic autofluorescence microspectro-imaging of bronchi and alveoli // Proc SPIE. 2008; 6851.

22. Qu J., MacAulay C., Lam S. Laser-induced fluorescence spectroscopy at endoscopy: tissue optics, Monte Carlo modeling and in vivo measurements // Opt. Eng. 1995; 34: 3334-3343.

23. Lane P.M., Lam S., McWilliams A., Leriche J.C., Anderson M.W., Macaulay C.E. Confocal uorescence microendoscopy of bronchial epithelium // J. Biomed. Opt. 2009; 14: 024008.

24. Jean F., Bourg-Heckly G., Viellerobe B. Fibered confocal spectroscopy and multicolor imaging system for in vivo fluorescence analysis // Opt. Express. 2007; 15: 40084017.

25. Becker V., von Delius S., Bajbouj M., Karagianni A., Schmid R.M., Meining A. Intravenous application of fluorescein for confocal laser scanning microscopy: evaluation of contrast dynamics and image quality with increasing injection-to-imaging time // Gastrointest Endosc. 2008; 68: 319-323.

26. Kiesslich R., Fritsch J., Holtmann M., Koehler H.H., Stolte M., Kanzler S., Nafe B., Jung M., Galle P.R., Neurath M.F. Methylene blue-aided chromoendoscopy for the detection of intraepithelial neoplasia and colon cancer in ulcerative colitis // Gastroenterology. 2003; 124: 880-888.

27. Taghavi S.A., Membari M.E., Eshraghian A., Dehghani S.M., Hamidpour L., Khademalhoseini F. Comparison of chromoendoscopy and conventional endoscopy in the detection of premalignant gastric lesions // Can. J. Gastroenterol. 2009; 23: 105-108. 
28. Marion J.F., Waye J.D., Present D.H., Israel Y., Bodian C., Harpaz N., Chapman M., Itzkowitz S., Steinlauf A.F., Abreu M.T., Ullman T.A., Aisenberg J., Mayer L. Chromoendoscopy-targeted biopsies are superior to standard colonoscopic surveillance for detecting dysplasia in inflammatory bowel disease patients: a prospective endoscopic trial // Am. J. Gastroenterol. 2008; 103: 2342-2349.

29. Inoue H., Kazawa T., Sato Y., Satodate H., Sasajima K., Kudo S.E., Shiokawa A. In vivo observation of living cancer cells in the esophagus, stomach, and colon using catheter-type contact endoscope, "Endo-Cytoscopy system" // Gastrointest. Endosc. Clin. N Am. 2004; 14: 589-594.

30. Shibuya K., Fujiwara T., Yasufuku K., Alaa M., Chiyo M., Nakajima T., Hoshino H., Hiroshima K., Nakatani Y., Yoshino I. Endo-cytoscopy system is a novel endoscopic technology to visualize microscopic imaging of the tracheobronchial tree // Eur. Respir. J. 2008; 32: Suppl. 52, 263s.

31. Mercer R.R., Crapo J.D. Spatial distribution of collagen and elastin fibers in the lungs // J. Appl. Physiol. 1990; 69: 756-765.

32. Weibel E.R., Sapoval B., Filoche M. Design of peripheral airways for efficient gas exchange // Respir. Physiol. Neurobiol. 2005; 148: 3-21.
33. Weibel E.R., Hsia C.C., Ochs M. How much is there really? Why stereology is essential in lung morphometry // J. Appl. Physiol. 2007; 102: 459-467.

34. Black P.N., Ching P.S., Beaumont B., Ranasinghe S., Taylor G., Merrilees M.J. Changes in elastic fibres in the small airways and alveoli in COPD // Eur. Respir. J. 2008; 31: 998-1004.

35. Honda T., Ota H., Arai K., Hayama M., Fujimoto K., Yamazaki Y., Haniuda M. Three-dimensional analysis of alveolar structure in usual interstitial pneumonia // Virchows Arch. 2002; 441: 47-52.

36. Honda T., Ota H., Sano K. et al. Alveolar shrinkage in bronchioloalveolar carcinoma without central fibrosis // Lung Cancer. 2002; 36: 283-288.

37. Hsu E.R., Gillenwater A.M., Hasan M.Q., Williams M.D., El-Naggar A.K., Richards-Kortum R.R. Real-time detection of epidermal growth factor receptor expression in fresh oral cavity biopsies using a molecular-specific contrast agent // Int. J. Cancer. 2006; 118: 3062-3071.

38. Hsiung P.L., Hardy J., Friedland S., Soetikno R., Du C.B., Wu A.P., Sahbaie P., Crawford J.M., Lowe A.W., Contag C.H., Wang T.D. Detection of colonic dysplasia in vivo using a targeted heptapeptide and confocal microendoscopy // Nat. Med. 2008; 14: 454-458. 


\title{
КОНФОКАЛЬНАЯ МИКРОСКОПИЯ IN VIVO: ОТ ПРОКСИМААЬНЫХ БРОНХОВ К ААЬВЕОЛЯРНОМУ АЕРЕВУ АЕГКИХ
}

\author{
Тибервилль Л., ${ }^{1,2}$ Салаун M.1,2, Бург-Хекли Дюж. ${ }^{3}$ \\ ${ }^{1}$ КАиника Руанского университета \\ 2 LITIS EA 4108 (группа Quant-IF), ффакультет медицины и фрармакологии, Руан \\ ${ }^{3}$ UMR CNRS 7033, BioMoCеTi, Университет Пьера и Марии Кюри - Paris 6, France
}

\begin{abstract}
В условия in vivo эндоскопическая микроскопия направлена на то, чтобы предоставить врачу средство для оценки архитектуры и морфологии живых тканей в режиме реального времени, обеспечив при этом оптическое разрешение, сходное с разрешением при стандартном гистопатологическом исследовании. На сегодняшний день доступные микроэндоскопические устройства используют принцип флуоресцентной конфокальной микроскопии и вследствие этого в основном выполняют анализ пространственного распределения специфических эндогенных или экзогенных флуорофоров. Флуоресцентные микроэндоскопы, предназначенные для исследования дыхательной системы, используют пучок оптоволокон, который вводится в рабочий канал бронхоскопа. Такой мини-зонд может применяться в условиях in vivo для исследования внутренней поверхности бронхов или продвигаться в дистальные бронхиолы, вплоть до ацинуса, чтобы в условиях in situ, in vivo выполнить микроскопическую визуализацию дыхательных путей в режиме реального времени. Флуоресцентная конфокальная микроэндоскопия дает возможность визуализации эпителиальных и субэпителиальных слоев проксимальных отделов бронхиального дерева, а также дистальных отделов легких, от конечных бронхиол до альвеолярных протоков и альвеол. Потенциальные области применения включают в себя микроскопическую оценку в условиях in vivo ранних стадий рака бронхов, оценку ремоделирования бронхиальной стенки и исследования диффузных заболеваний периферических отделов легких, а также диагностики in vivo узелковых образований в периферических отделах легких. Данный метод также имеет потенциальную возможность совместного использования с флуоресцентной молекулярной визуализацией. В этой статье описаны возможности и вероятные ограничения конфокальной микроэндоскопии для исследования проксимальных и дистальных отделов легких.
\end{abstract}

Ключевые слова: бронхоскопия, конфокальная микроскопия, микровизуализачия in vivo, предраковые состояния, конфокальная лазерная эндомикроскопия с применением зондов, альвеолы легких.

В настоящее время благодаря последним достижениям в области оптики и компьютерной техники диагностическая эндоскопия дыхательных путей вступила в эпоху микроскопических изображений $[1,2]$. Доступные на текущий момент микроэндоскопические устройства используют принцип конфокальной флуоресцентной микроскопии, в котором объектив микроскопа заменен оптическим волокном, проводящим как возбуждающий свет в ткани, так и флуоресценцию тканей от дистального конца оптического волокна обратно. Такие системы на границе с дистальной частью оптики анализируют пространственное распределение конкретных флуорофоров в ткани, или же экзогенных флуорофоров. За последние пять лет флуоресцентная конфокальная микроэндоскопия была успешно применена для исследования in vivo слизистой оболочки желудка и толстого кишечника, желчевыводящих путей [3-6] и, совсем недавно, для получения микроскопических изображений проксимальных и дистальных отделов бронхиального дерева $[7,8]$.

Возможность использования конфокальной микроскопии в клинических условиях для проведения эндомикроскопических исследований in vivo является итогом большой научно-исследовательской работы $[9,10]$, которая недавно завершилась выпуском коммерческих систем. Эти системы предназначены для исследования легких как животных [11-13], так и человека $[5,7,8,14]$. Учитывая проблемы, связанные с небольшими размерами терминальных отделов бронхиального дерева человека и их относительной труднодоступностью, в респираторных эндомикроскопических системах применяют оптоволоконную флуоресцентную конфокальную микроскопию (FCFM) или конфокальную микроскопию с использованием катетера.

\section{ПРИНЦИПЫ ОПТОВОЛОКОННОЙ ФАУОРЕСЦЕНТНОЙ КОНФОКААЬНОЙ МИКРОСКОПИИ (FСFМ)}

Конфокальная микроскопия позволяет получать in vivo оптическое изображение клеток и тканей с повышенным боковым и осевым разрешением [9, 10], в результате чего происходит визуализация тонких «срезов» образца. Принцип конфокальной микроскопии заключается в использовании для 
освещения узкого точечного источника и малой диафрагмы или отверстия в тракте улавливания света. Лазерный источник (точечный источник) фокусируется на одной точке образца, и свет, испускаемый в этой фокальной точке, попадает на фотоприемник через отверстие диафрагмы. Поэтому вся нефокусная информация о структурах исследуемого образца, которая находится выше и ниже очень тонкой фокусной плоскости, не визуализируется. Системы освещения и фотоприемника, которые являются сопряженными в одной и той же фокальной плоскости, называются «конфокальными». Для того чтобы получить двумерные изображения тканей, конфокальный микроскоп должен сканировать образец в поперечном и продольном направлениях.

Респираторные конфокальные микроэндоскопы отличаются техническим подходом к визуализации тканей от первых конфокальных флуоресцентных эндоскопов, которые использовали для визуализации желудочно-кишечного тракта. В эндомикроскопах Optiscan ${ }^{\circledR} /$ Pentax, созданных для исследования желудочно-кишечной системы [15], используют небольшую сканирующую головку (длина 4,5 см, диаметр 3,5 мм), которую присоединяют к дистальному концу эндоскопа. Эндомикроскопические изображения желудочно-кишечного тракта, полученные при помощи устройства Optiscan ${ }^{\circledR} /$ Pentax, с боковым разрешением менее 1 мкм и оптическими «срезами» глубиной 7 мкм, очень близки к традиционной гистологии. Размер зоны визуализации при этом составляет $475 \times 475$ мкм. Эта система имеет два недостатка, которые не позволяют использовать ее для визуализации дыхательных путей. Первым из них являются слишком большие размеры сканирующей головки, рабочего канала, а также использование обычного светового тракта и ПЗС-камеры. В настоящее время диаметр дистального конца эндоскопа составляет 12 мм, что едва ли совместимо с проведением исследования человеческой трахеи и крупных основных бронхов. Во-вторых, миниатюризация сканирующей головки приводит к уменьшению скорости сканирования до одного кадра в секунду. Поэтому для получения четких микроскопических изображений эпителия требуется очень точная система стабилизации дистального наконечника эндоскопа на слизистой оболочке.

На сегодняшний день единственным коммерчески доступным конфокальным эндомикроскопом для исследований дыхательных путей является изделие Cellvizio ${ }^{\circledR}$, выпускаемое компанией Mauna
Kea Technologies (Париж, Франция). Этот эндомикроскоп также позволяет проводить исследование желудочно-кишечного тракта. В нем используется принцип проксимального сканирования, при котором лазерная подсветка сканирует проксимальную часть когерентного пучка оптоволокна или минизонда. Этот пучок проводит свет в оба направления от области, отображаемой на наконечнике мини-зонда. Подсветка, сканирование, спектральная фильтрация и система визуализации расположены в проксимальной части устройства, дистальная часть устройства состоит из отдельного мини-зонда, который включает в себя оптоволоконный пучок и разъем для его подключения к блоку лазерного сканирования (рис. 1).

Эта система на основе оптоволоконного пучка, которая также может быть описана как оптоволоконный флуоресцентный конфокальный микроскоп (FCFM), использует очень тонкие и гибкие минизонды (300 мкм - 2 мм в диаметре), в которых может содержаться до 30000 компактно уложенных волокон. Подобно традиционным конфокальным микроскопам, система FCFM включает два быстро двигающихся зеркала для сканирования микроволокон поперек когерентного пучка оптоволокна в виде растра. Каждое микроволокно, сканируемое по очереди при помощи лазера, действует как система подведения и сбора света и является, по сути, самостоятельным отверстием диафрагмы.

Основными преимуществами такой конструкции является очень малый размер зонда, который можно ввести в бронхиолы, а также высокая скорость получения изображений, что помогает избежать возникновения артефактов, связанных с движением тканей.

Специальные мини-зонды для получения изображений бронхиальных и альвеолярных отделов имеют диаметр 1 мм, что в два раза меньше диаметра альвеолярной полости (рис. 1). Эти минизонды могут вводиться в рабочие каналы диаметром 2 мм, которыми оснащены бронхоскопы для взрослых, и достигают любой части легкого, за исключением верхушечных и задних сегментов обеих верхних долей, что объясняется относительной жесткостью дистальной части зонда (рис. 2) [8]. Респираторные мини-зонды лишены дистальной оптики и имеют глубину фокуса 0-50 мкм, боковое разрешение 3 мкм для поля обзора величиной $600 \times$ 600 мкм. Система обеспечивает эндомикроскопическую визуализацию со скоростью 9-12 кадров в секунду.

Тибервилль Л. - руководитель отделения пульмонологии, университетский госпиталь, Руан, Франция. Салаун М. - научный сотрудник. Университетский госпиталь, г. Руан, клиника пульмонологии. Дж. Бург-Хекли - научный сотрудник. Университет Пьера и Марии Кюри, г. Париж.

Для корреспонденции: Тибервилль Л. Тел.: +3323288 82 47. E-mail: luc.thiberville@univ-rouen.fr. 
a

Лазерный

источник света
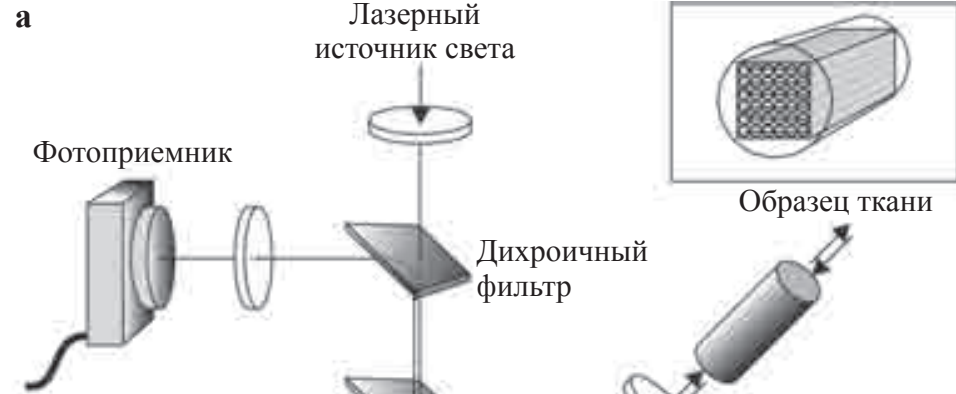

Образец ткани
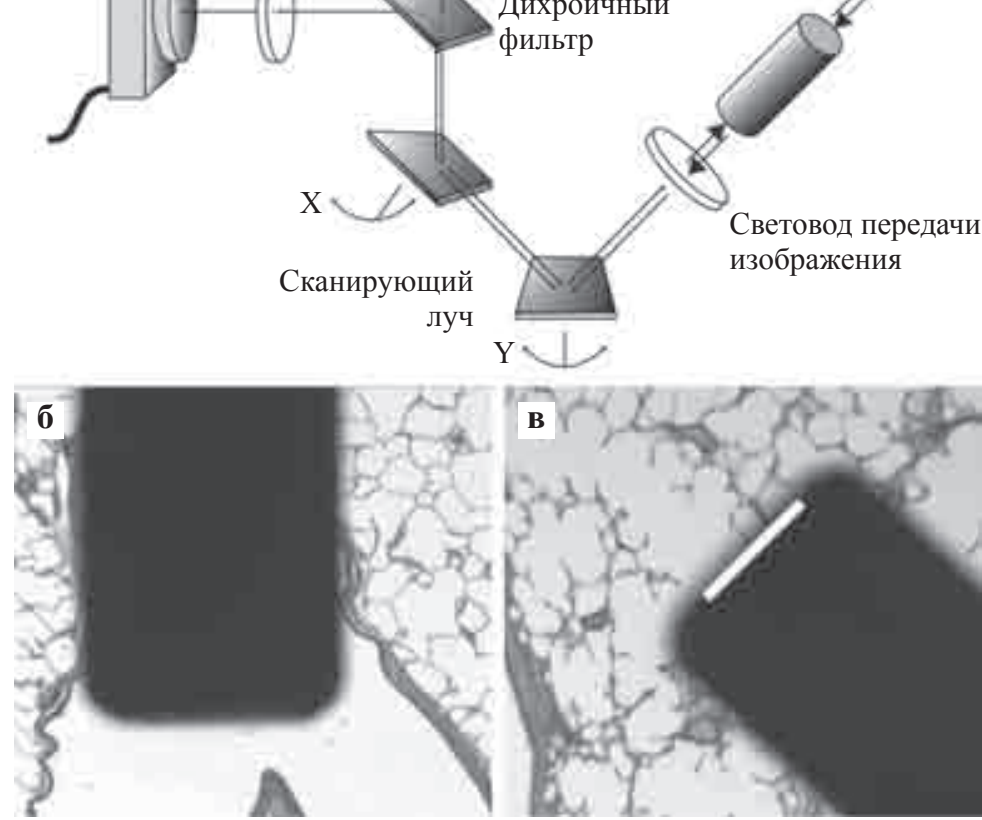

Рис. 1. Принципиальная схема (а) оптоволоконного конфокального флуоресцентного микроскопа (Cellvizio ${ }^{\circledR}$, Mauna Кеa Technologies, Париж, Франция) и относительные размеры 1,4-мм наконечника мини-зонда Alveoflex ${ }^{\circledR}$ бронхиальных (б) и альвеолярных (в) структур. Белая полоса соответствует диаметру оптоволоконного пучка и зоне обзора (600 мкм) [8]

a
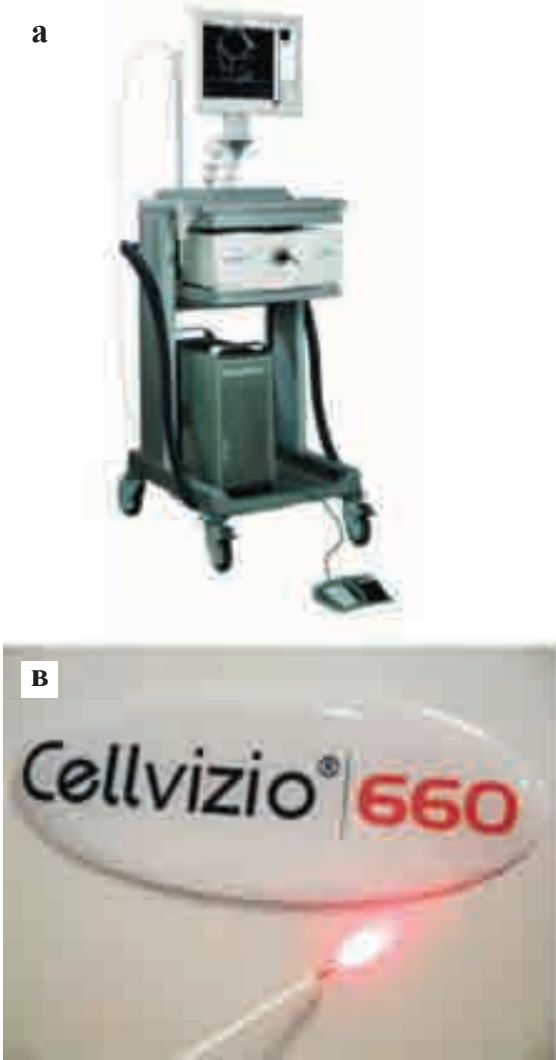

б
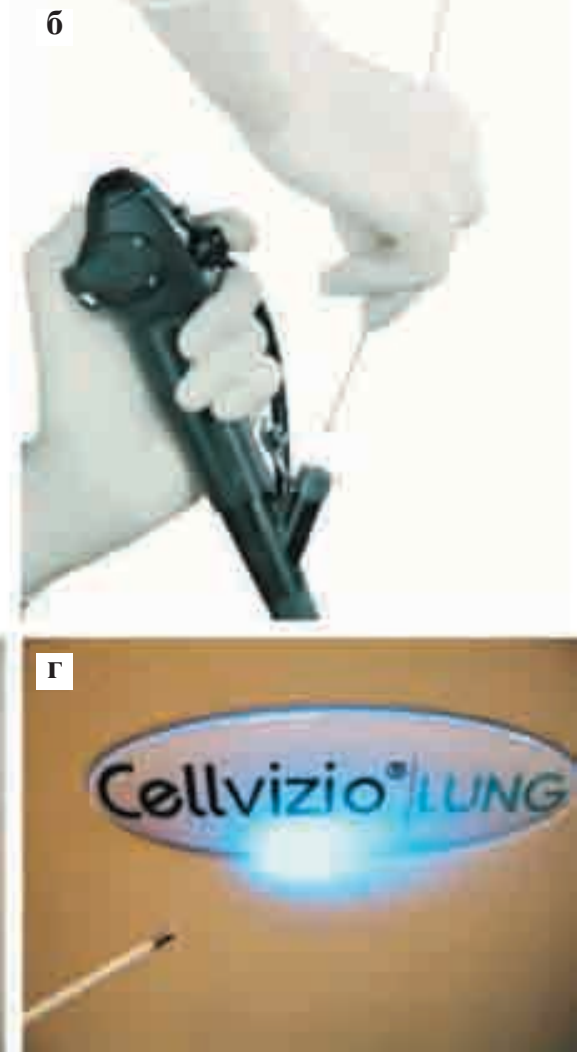

Рис. 2. Системы оптоволоконного конфокального флуоресцентного микроскопа Cellvizio ${ }^{\circledR}$ и специальные мини-зонды для исследования легких (Mauna Kea Technologies, Париж, Франция): a - устройство Cellvizio ${ }^{\circledR}$; 6 - мини-зонд Alveoflex $^{\circledR}$, вводимый в рабочий канал бронхоскопа; в - красный свет с длиной волны 660 нм, производимый устройством Cellvizio $^{\circledR}$ 660; г- синий свет с длиной волны 488 нм, производимый устройством Cellvizio ${ }^{\circledR}$ Lung 
Возможно использование света с двумя различными длинами волн (рис. 2). Устройство Cellvizio ${ }^{\circledR}$ с длиной волны 488 нм применяют для аутофлуоресцентной визуализации респираторного тракта, а также для визуализации с наведенной флуоресценцией желудочно-кишечного тракта [6-8]. В другом устройстве для возбуждения используется свет с длиной волны 660 нм, который позволяет осуществлять визуализацию эпителиальных клеток после поверхностного нанесения экзогенных флуорофоров, например, метиленового синего [16-18].

Основными ограничениями системы являются ее разрешающая способность (максимальное разрешение 30000 пикселей; боковое разрешение ограничивается 3 мкм между волокнами) и фактическое отсутствие возможности регулировки фокуса системы. Интерпретация данных зависит от люминесцентных свойств исследуемой ткани.

\section{КОНФОКАЛЬНАЯ МИКРОВИЗУААИЗАЦИЯ HОРМААЬНЫХ АЕГКИХ ЧЕАОВЕКА IN VIVO ПРИ ПОМОЩИ ОПТОВОАОКОННОГО ФАУОРЕСЦЕНТНОГО КОНФОКААЬНОГО МИКРОСКОПА}

Ранние эксперименты в условиях ex vivo с использованием свежих образцов легких взрослого человека показали, что при длине волны возбуждения в 488 нм FCFM позволяет получить волоконно-оптические изображения, соответствующие аутофлуоресценции соединительной ткани терминальных отделов бронхиального дерева (рис. 3). Это позволило при бронхоскопии человека в условиях in vivo проводить микроскопическое исследование от проксимальных отделов бронхиального дерева вплоть до самых отдаленных дистальных структур, включая альвеолы.

\section{Природа аутофмуоресценции \\ бронхиальных и альвеолярных структур}

При длине волны возбуждения 488 нм флуоресцентные свойства слизистой оболочки бронхов определяются концентрацией различных клеточных и внеклеточных флуорофоров, в том числе внутриклеточных флавинов, которые могут производиться эпителиальными клетками, а также особых связок коллагенов и эластина, которые присутствуют в субэпителиальных областях $[10,19,20]$. Микроспектрометрические эксперименты в сочетании c FCFM-визуализацией наглядно продемонстрировали, что при возбуждении светом с длиной волны 488 нм основной флуоресцентный сигнал исходит и от бронхов, и от альвеол легких человека, а его ис- точником является эластин (рис. 4) [7, 8, 21]. Флуоресценция же коллагена при этой длине волны, по меньшей мере, на порядок более низкая, чем у эластина. Аутофлуоресценция клеточного флавина слишком слабая для визуализации эпителиального слоя при использовании оптоволоконного конфокального флуоресцентного микроскопа с длиной волны возбуждения 488 нм [22].

Используя волны более короткой длины, устройства оптоволоконной флуоресцентной конфокальной микроскопии могут производить несколько различающиеся изображения соединительной ткани бронхиальной стенки (рис. 3). Тем не менее визуализация эпителиального слоя поверх сети базальной мембраны требует иного подхода. В настоящее время доступным способом является использование экзогенных флуоресцентных красителей $[18,23]$. В будущем устройства, основанные на использовании нескольких длин волн [24], с присоединением отражательного устройства [10] или использующие многофотонный способ [9], позволят осуществлять одновременную визуализацию коллагена, эластина и флавинов.

В результате устройства оптоволоконной флуоресцентной конфокальной микроскопии с длиной волны возбуждения 488 нм осуществляют визуализацию в дыхательных путях эластина, который содержится в базальной мембране проксимальных отделах дыхательных путей (бронхах), а также в интерстиции паренхимы легких.

\section{Аутофмуоресцентные микроизображения in vivo стенок проксимальных бронхов}

Оптоволоконная флуоресцентная конфокальная микроскопия легко может быть выполнена во время оптоволоконной бронхоскопии, проводимой под местной анестезией $[7,8]$. Техника бронхиальной FCFM - визуализации in vivo проста: мини-зонд вводится в рабочий канал бронхоскопа диаметром 2 мм, и наконечник зонда подводится к слизистой оболочке бронха под визуальным контролем. Глубина фокусировки составляет 50 мкм ниже поверхности контакта, система в состоянии сделать снимок первых слоев бронхиальной субэпителиальной соединительной ткани [7].

При возбуждении свечения с длиной волны 488 нм оптоволоконная флуоресцентная конфокальная микроскопия позволяет получать очень точные микроскопические флуоресцентные изображения зоны базальной мембраны бронхов. Как видно на рис. 5, бронхиальные микроизображения in vivo показывают слой крупных волокон, которые ориентированы в основном вдоль продольной оси дыхательных путей и имеют поперечные связи из более мелких волокон, а также более крупные 

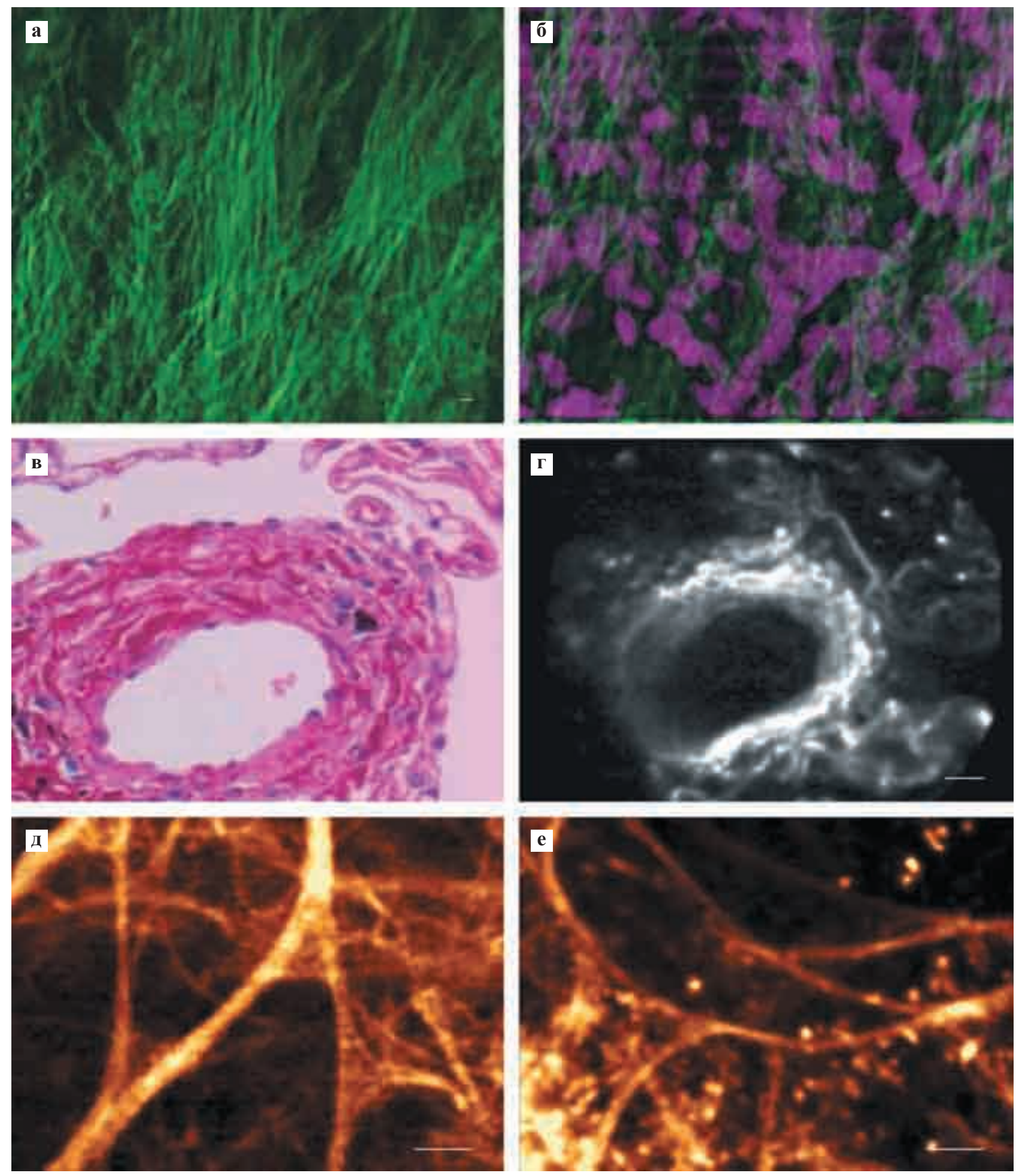

Рис. 3. Конфокальная микроскопия ex vivo биопсии бронхов и легких: а и б - визуализация тканей бронхов в нефиксированных биоптатах легких конфокальной флуоресценцией и отражением; а - аутофлуоресцентное изображение подслизистой оболочки примерно на 25-30 мкм ниже поверхности, длина волны подсветки 437 нм; б - отраженное свечение ядер клеток (красно-фиолетовое свечение) и наложение аутофлуоресцентного изображения (зеленое свечение); в и г - предальвеолярная бронхиола и прилегающие стенки альвеол, фиксированный срез легких; в - традиционная гистология; г - соответствующее изображение, полученное при помощи оптоволоконной флуоресцентной конфокальной микроскопии (аутофлуоресценция, длина волны подсветки 488 нм); д и е - ex vivo изображение, полученное при помощи оптоволоконной флуоресцентной конфокальной микроскопии (FCFM) среза свежей паренхимы легких (длина волны подсветки 488 нм); д - аутофлуоресценция эластических волокон на границе бронхиолы и альвеолярного устья; е - изображение, полученное после нанесения акрифлавина на срез легкого; в дополнение к свечению эластина альвеол флуоресцируют ядра пневмоцитов, окрашенные акрифлавином. Масштаб: а - 10 мкм; г-е - 50 мкм. а и б - предоставлено С. Макаули, Исследовательский центр рака Британской Колумбии, Ванкувер, Британская Колумбия, Канада; в и г - воспроизведено из [8]; д и е - L. Thiberville, Клиника Руанского университета, Руан, Франция 

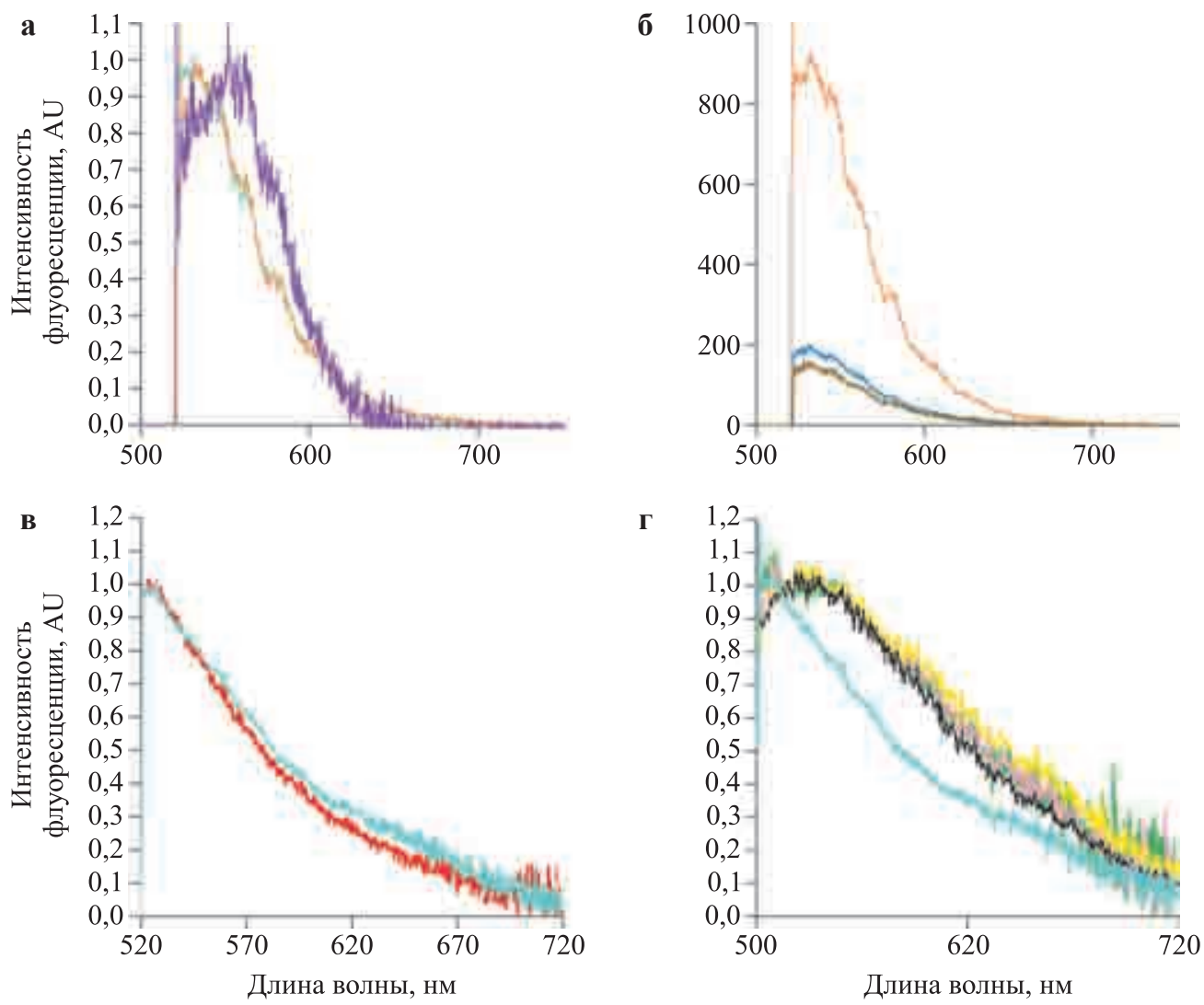

Рис. 4. Природа оптоволоконной флуоресцентной конфокальной микроскопии (аутофлуоресценция, длина волны подсветки 488 нм) в проксимальных бронхах и альвеолах как курильщиков, так и некурящих, как было установлено спектрометрическими экспериментами in vivo: а - типичный нормализованный спектр аутофлуоресценции здоровой слизистой оболочки бронхов (оранжевый), порошкового эластина (бледно-голубой) и коллагена (фиолетовый) при возбуждении 488 нм; б - аутофлуоресцентный спектр здоровой слизистой оболочки бронхов (оранжевый), карциномы (темно-синий) и синдрома Мунье-Куна (коричневый) при возбуждении 488 нм. Аутофлуоресцентный спектр излучения альвеолярной системы: в - у некурящих (красный); г - здоровых курильщиков (зеленый, розовый, желтый), во время альвеоскопии in vivo; в и г - бледно-голубой: эластин порошковый; г - черный: выкуренная сигарета. AU: произвольные единицы (а и б - воспроизведено из [7], с разрешения издателя, в и г - [8])

отверстия (размером 100-200 мкм), соответствующие протокам бронхиальных желез. Техника исследований in vivo также делает возможной запись изображений с высоким разрешением малых дыхательных путей, таких как концевые бронхиолы, которые узнаваемы по наличию спирального отпечатка гладкой мускулатуры на внутренней части бронхиолы [7].

Применение систем визуализации с помощью оптоволоконной флуоресцентной конфокальной микроскопии для исследования заболеваний проксимальных бронхов все еще находится в начальной стадии. Ранее были опубликованы результаты исследования стенки бронхов при их доброкачественном [7] и преинвазивном поражении [7, 18].

\section{ОЦЕНКА IN VIVO СТЕНКИ БРОНХОВ}

Полученные при помощи оптоволоконной флуоресцентной конфокальной микроскопии изображе- ния показывают, что микроструктура бронхиальной стенки при предраке значительно изменена [7]. При предраковом состоянии в большинстве случаев исчезают упругие волокнистые структуры базальной мембраны, а их дезорганизация имеет место примерно в одной трети наблюдений, что поддерживает гипотезу о ранней деградации компонентов базальной мембраны при преинвазивном поражении бронхов (рис. 6). Вопрос о том, связано ли раннее ремоделирование ретикулярной мембраны с конкретными результатами поражения, подлежит дополнительному изучению.

Однако, несмотря на то что это наблюдение пролило некоторый свет на происхождение дефекта аутофлуоресценции предраковых бронхиальных поражений, отсутствие в данном исследовании визуализации эпителиальных клеток не позволяет технике различать in situ различные степени прогрессирования предраковых бронхиальных поражений, таких как метаплазия / дисплазия / карцинома (см. раздел об оценке слоя бронхиальных 

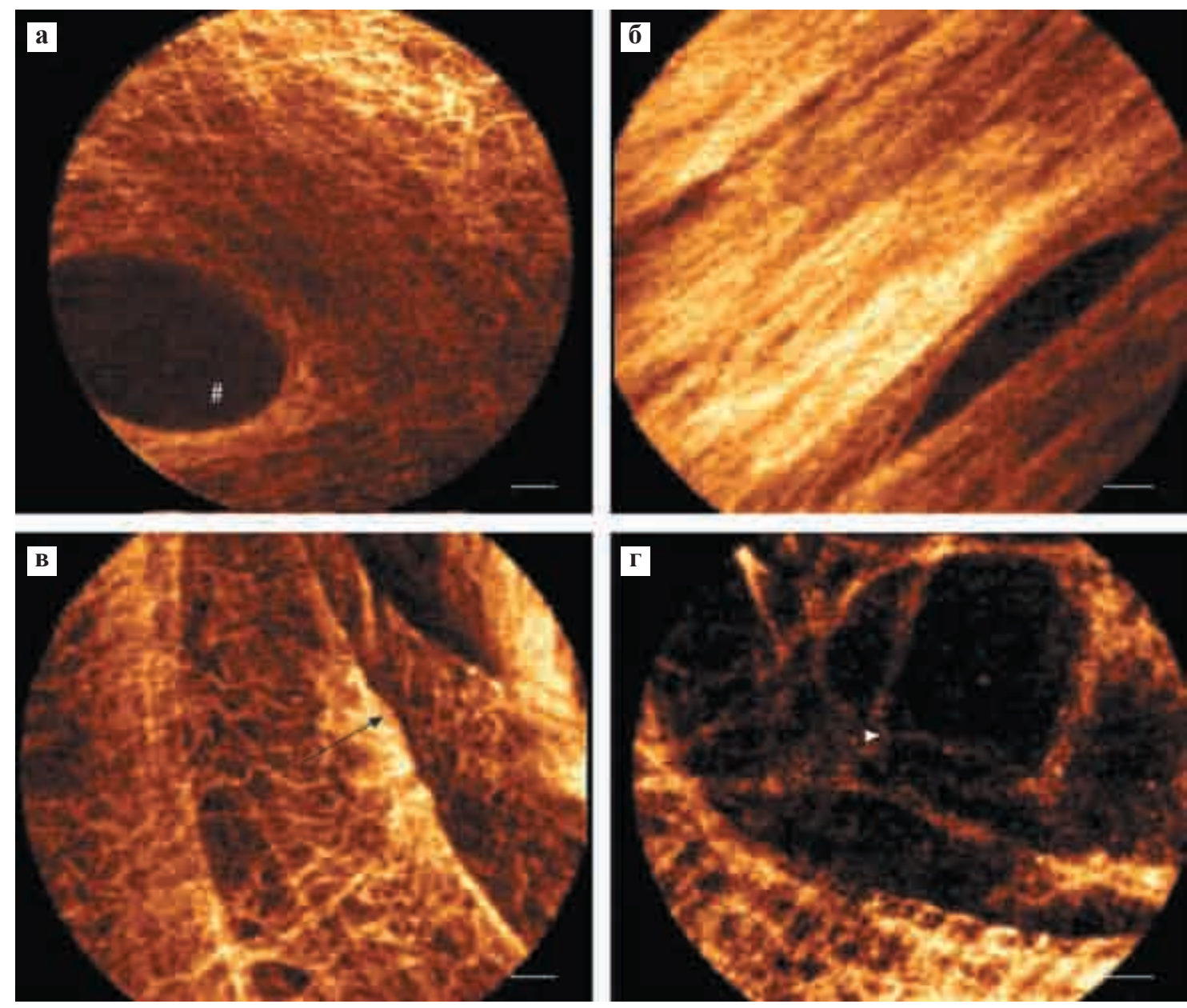

Рис. 5. Изображение in vivo, полученное при помощи оптоволоконной флуоресцентной конфокальной микроскопии человеческих бронхов и бронхиол: а - проксимальный бронх, протока бронхиальной железы (\#); б - главный бронх, упругая волокнистая структура, ориентированная вдоль продольной оси дыхательных путей; в - дистальная бронхиола, показывающая спиральный виток гладких мышц (стрелка); г - переходная бронхиола, показывающая начало альвеолы (конец стрелки). Масштаб: 50 мкм

эпителиальных клеток при помощи оптоволоконной флуоресцентной конфокальной микроскопии и рис. 6).

Кроме изучения предраковых изменений бронхиальной стенки применение оптоволоконной флуоресцентной конфокальной микроскопии может быть расширено на область доброкачественных бронхиальных заболеваний. В одном исследовании, при синдроме трахеомегалии, патологическом состоянии, связанном с дефектом упругого компонента бронхиальной стенки [7], наблюдалось полное исчезновение волокнистых соединительных структур бронхиальной стенки. В том же исследовании также отмечен значительный аспект FCFM в случае саркоидоза, соответствующий субэпителиальным гранулемам при отборе бронхиальных образцов. Хотя эти наблюдения все еще являются ограниченными, они показывают, что эндоскопическая оптоволоконная флуоресцентная конфокальная микроскопия может быть использована для изучения ремоделирования базальной мембраны, например, при хронических бронхите, астме и хронической обструктивной болезни легких.

\section{ОЦЕНКА ЭПИТЕАИАЛЬНЫХ КАЕТОК БРОНХОВ ПРИ ПОМОЩИ ОПТОВОАОКОННОЙ ФАУОРЕСЦЕНТНОЙ КОНФОКААЬНОЙ МИКРОСКОПИИ}

Для того чтобы успешно применять оптоволоконную флуоресцентную конфокальную микроскопию при исследовании предракового / ракового эпителия бронхов, необходимо дополнительно использовать нетоксичные экзогенные флуорофоры. Исследования ex vivo показали, что разрешающая способность системы не является ограничением для получения изображений ядер или клеток $[7,8]$. Экзогенные флуорофоры, которые могут быть активированы при длине волны возбуждения 488 нм, такие как акрифлавин (предполагаемый мутагенный агент) или раствор флуоресцеина, который не окрашивает ядра [25], не одобрены для внутриброн- 

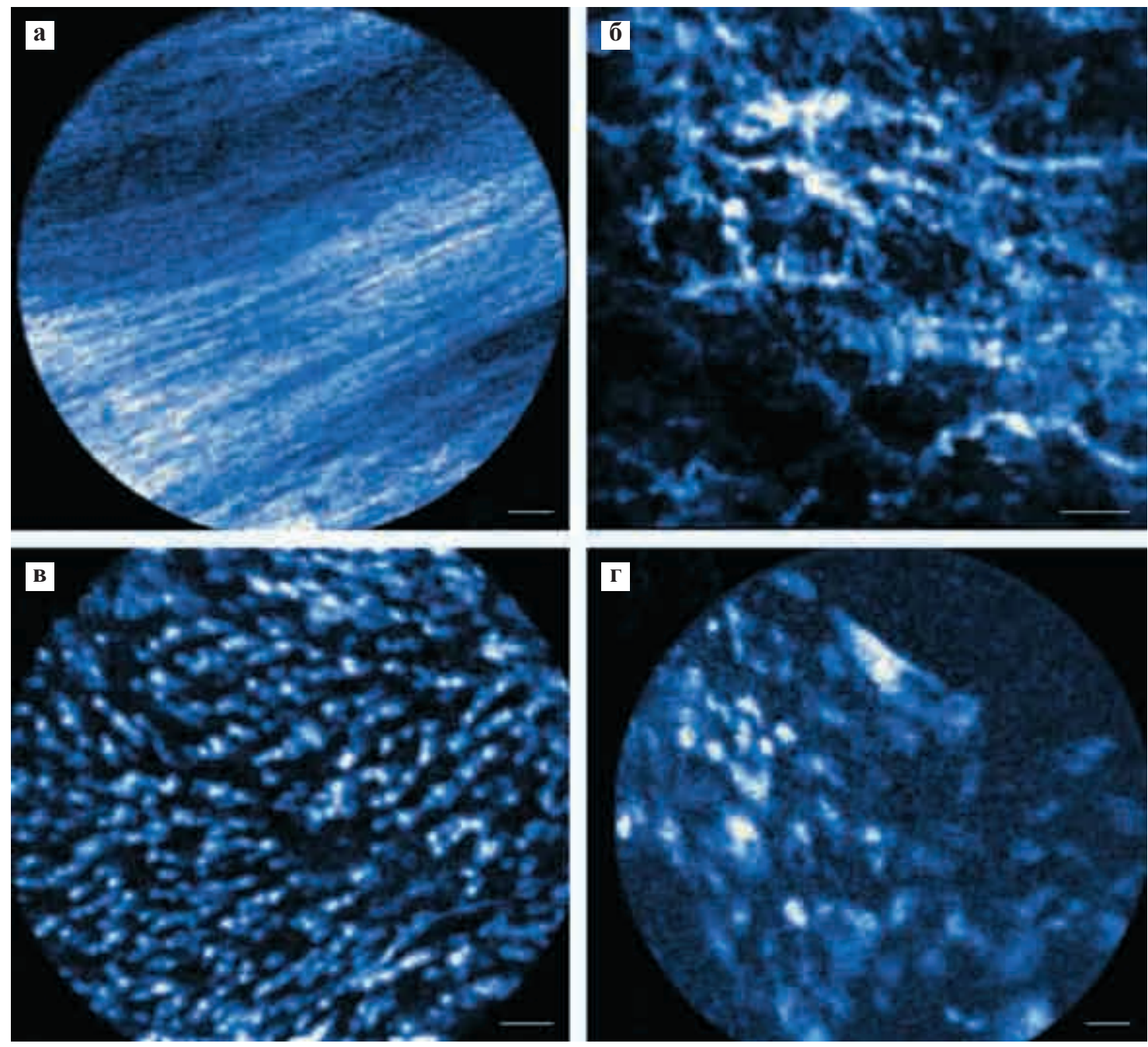

Рис. 6. Эпителиальные и субэпителиальные изображения, полученные при конфокальной микроэндоскопии нормальной ткани и предраковых поражений: а - нормальная упругая волокнистая структура в зоне базальной мембраны; б - дезорганизация волокнистой структуры зоны базальной мембраны в непосредственной близости от бронхиальной карциномы in situ (CIS); в - нормальный эпителий бронхов с регулярной структурой; г - CIS; а и б - изображения, полученные при длине волны возбуждения 488 нм без экзогенных флуорофоров (Cellvizio ${ }^{\circledR} 488$ ) - в этих условиях обнаружению и визуализации поддается только эластин базальной мембраны; в и г получены при длине волны возбуждения 660 нм и с поверхностным использованием метиленового синего $(0,1 \%)$, для того чтобы визуализировать эпителиальный слой $\left(\right.$ Cellvizio $\left.^{\circledR} 660\right)$. Все изображения были записаны in vivo при бронхоскопии, но с двумя разными блоками лазерного сканирования (Cellvizio ${ }^{\circledR} 488$ и 660; Mauna Kea Technologies, Париж, Франция, Париж, Франция). Масштаб: а, в, г- 50 мкм; б - 40 мкм [7]

хиального использования. Недавно Лейн и соавт. [23] использовали прототип конфокального микроэндоскопа при длине волны возбуждения 488 нм и поверхностный физиологический $\mathrm{pH}$ крезиловый фиолетовый краситель для обеспечения контраста клеток бронхиального эпителия как in vitro, так и in vivo.

Метиленовый синий является нетоксичным агентом, который обычно используется при бронхоскопии для диагностики бронхоплевральных свищей. Он также используется в гастроэнтерологии для хромоэндоскопического обнаружения предраковых поражений [26-28], а также для микроскопических исследований in vivo желудочно-кишечного тракта и бронхов с использованием новой эндоцитоскопи- ческой системы $[29,30]$. Метиленовый синий является мощным флуорофором, который входит в ядра и обратимо связывается с ДНК, прежде чем будет поглощен лимфатической системой. Для того чтобы дать флуоресцентный сигнал, метиленовый синий должен быть возбужден при длине волны около 660 нм, и следовательно, доступен для прижизненной визуализации с применением оптоволоконной флуоресцентной конфокальной микроскопии, в которой используется эта длина волны возбуждения.

Предварительные исследования показали, что применение устройства Cellvizio ${ }^{\circledR} 660$ и поверхностное нанесение метиленового синего позволяет визуализировать эпителиальный слой главных бронхов (рис. 6) [18]. Дальнейшие исследования с помощью 
этой техники могут сделать возможной дифференциацию in vivo нормальных тканей, предраковых и злокачественных изменений на микроскопическом уровне. Если эта стратегия станет успешной, то оптоволоконная флуоресцентная конфокальная микроскопия может стать очень мощным средством для диагностики in vivo ранних злокачественных и предраковых состояний бронхиального дерева, позволяя анализировать как эпителиальные, так и субэпителиальные слои во время одной и той же процедуры.

\section{ВИЗУААИЗАЦИЯ АИСТААЬНОЙ И ПЕРЕХОАНОЙ ЧАСТИ БРОНХОВ}

При продвижении в сторону более дистальных отделов бронхиального дерева небольшие нехрящевые бронхиолы легко узнаваемы из-за спирального расположения гладкомышечных клеток в стенке бронхов (рис. 5). Тем не менее ортогональное ветвление и малый диаметр конечных и респираторных бронхиол у человека, сравнимый с размером зонда, подразумевает, что продвижение зонда к ацинусу обычно обходит переходные бронхиолы дыхательных путей. Хотя и можно случайно наблюдать FCFM-изображения альвеолярных зачатков в дыхательных бронхиолах (рис. 5) [8], проведение исследования дистальных мембран и дыхательных бронхиол при помощи оптоволоконной флуоресцентной конфокальной микроскопии представляется затруднительным, если только в будущем не станут клинически доступными более тонкие зонды, в настоящее время используемые для экспериментальной визуализации на животных [13].

\section{ВИЗУААИЗАЦИЯ АЦИНУСА И ПЕРИФЕРИЙНОЙ СТРУКТУРЫ СОЕАИНИТЕАЬНОЙ ТКАНИ ПРИ ПОМОЩИ ОПТОВО^ОКОННОЙ ФАУОРЕСЦЕНТНОЙ КОНФОКААЬНОЙ МИКРОСКОПИИ}

Более ранние работы показали, что содержание эластина достигает $50 \%$ в волокнах периферической соединительной ткани легких [31]. После первых работ на проксимальных бронхах оптоволоконная флуоресцентная конфокальная микроскопия быстро была применена для визуализации также и структур дистальной части легкого [8]. В ацинусе эластин присутствует в стенке альвеол и в их воротах, а также в наружной оболочке межальвеолярных микрососудов $[32,33]$ (рис. 3 и 7).

Для микровизуализации дистальных отделов легких полезным оказывается использование небольшого бронхоскопа с рабочим каналом диаметром 2 мм, что позволяет более эффективно ориенти- ровать зонд в областях, представляющих интерес. Затем мини-зонд FCFM осторожно продвигается в дистальные бронхиолы до тех пор, пока не появится изображение альвеол. Во время проведения процедуры с визуализацией в режиме реального времени можно последовательно изучить несколько ацинарных областей, выбирая различные бронхиолы. После того как будут достигнуты альвеолы, зонд следует слегка отвести, пока не будет потерян контакт, чтобы убедиться, что эффект от сжатия альвеол зондом является минимальным.

Опыт получения FCFM-изображений альвеол in vivo показал, что методика очень хорошо переносится под местной анестезией, при спонтанном дыхании объекта, находящегося в сознании. Из-за отсутствия болевых рецепторов в бронхиальном дереве до субплеврального уровня проникновение мини-зонда в легочную долю через просвет бронхиолы происходит безболезненно [8]. Кроме того, ацинарная визуализация не связана со значительным кровотечением, в противоположность тому, что обычно наблюдается при трансбронхиальном отборе проб при биопсии. Это объясняется низким давлением в альвеолярных капиллярах, которое может быть изменено в процессе продвижения зонда, а также гладкой конструкцией наконечника зонда, который может смещать межальвеолярные микрососуды без их повреждения. Наш опыт обследования более чем 150 пациентов и здоровых добровольцев показал, что плевральные осложнения отсутствуют, несмотря на получение многочисленных оптических «срезов» легкого во время эндоскопии при спонтанном дыхании пациентов, находящихся в сознании.

\section{ВИЗУААИЗАЦИЯ АЦИНАРНОЙ ТКАНИ НЕКУРЯЩИХ ОБЪЕКТОВ, ВЫПОАНЕННАЯ ПРИ ПОМОЩИ ОПТОВОАОКОННОЙ ФАУОРЕСЦЕНТНОЙ КОНФОКААЬНОЙ МИКРОСКОПИИ}

Ацинарные изображения легко получить продвижением зонда на несколько сантиметров вперед после того, как эндоскоп будет зафиксирован в субсегментарном бронхе. В связи с соответствием размеров наконечника зонда и дистальных бронхов попадание в альвеолярное пространство происходит путем проникновения через дистальные бронхиолы.

У некурящих оптоволоконная флуоресцентная конфокальная микроскопия воспроизводит в основном изображения эластичных волокон, которые окружают альвеолярные полости, укрепляют виртуальную стенку альвеолярных протоков и окружающие межальвеолярные микрососуды (рис. 7). 

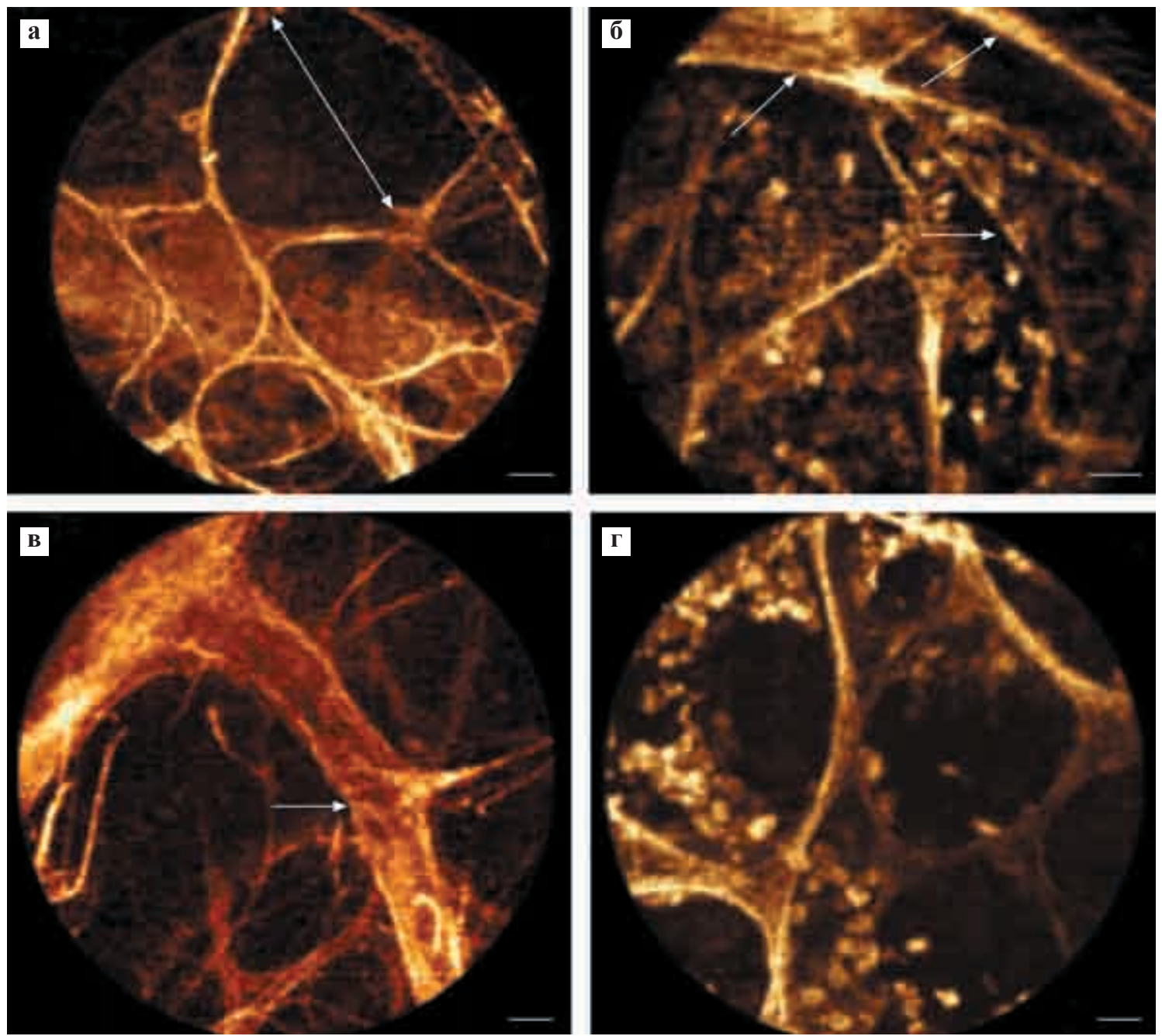

Рис. 7. Изображения in vivo, полученные при помощи оптоволоконной флуоресцентной конфокальной микроскопии во время альвеоскопии, подсветка 488 нм; а и в - некурящий пациент. Структура эластина: а - альвеолярного устья (диаметром 267,7 мкм - двойная стрелка); б - надальвеолярных капилляров (стрелка). 6 и г - FCFM-изображения альвеол курильщика, показаны альвеолярные стенки, края альвеолярных протоков (стрелки) и альвеолярных макрофагов. Масштаб: 50 мкм

При исследовании in vivo внешний вид этих дистальных упругих структур может меняться в зависимости от угла проникновения зонда в альвеолярный отдел. Обычно может быть получен прямой вид вниз по оси канала или косая проекция, в которых легко узнаваемыми являются «спиральная» или «петлеобразная» форма упругой структуры канала (рис. 7) [8].

Воспроизводимость этого способа была продемонстрирована на серии здоровых добровольцев, у которых размеры альвеолярного отверстия, измеренные на изображениях, полученных in vivo, показали нормальное распределение относительно среднего значения (около 275 мкм), что близко к тому, что наблюдается при использовании сложных стереологических методов исследования in vitro [32, 33], при толщине эластичных волокон, составляющей $10 \pm 2,7$ мкм (табл. и рис. 8) [8]. В опубликованной серии альвеолярные устья меньшего размера наблюдались в правой верхней доле и паракардиальном сегменте, что предположительно связано с нижней вентиляцией этих сегментов в положении лежа на спине [8]. Эта методика также позволяет проводить точные измерения надальвеолярных лобулярных микрососудов. Интересно, что у различных субъектов наблюдаются значительные отклонения в интенсивности сигнала флуоресценции, при этом у лиц преклонного возраста присутствует самый сильный сигнал, что указывает на структурные изменения перекрестных связей эластина легких по мере старения.

\section{АЦИНАРНАЯ И ААЬВЕОАЯРНАЯ ВИЗУААИЗАЦИЯ ААЯ АКТИВНЫХ КУРИАЬЩИКОВ}

Флуоресцентное изображение альвеол у активных курильщиков резко отличается от изображе- 
Таблица

Альвеолярная эндоскопия in vivo курящих и некурящих здоровых добровольцев

\begin{tabular}{|c|c|c|c|}
\hline & Курильщики & Некурящие & Bce \\
\hline Субъекты & 17 & 24 & 41 \\
\hline Возраст, лет & $37 \pm 16$ & $46 \pm 13$ & $42 \pm 15$ (диапазон 21-62) \\
\hline Продолжительность альвеолярной процедуры, мин & $14 \pm 6$ & $10 \pm 3$ & $11 \pm 5$ \\
\hline Диаметр альвеолярного устья, мкм & $274 \pm 52$ & $283 \pm 54$ & $278 \pm 53$ \\
\hline Измерения & 149 & 125 & 274 \\
\hline Толщина упругого волокна, мкм & $9,70 \pm 3,0$ & $10,38 \pm 2,34$ & $10,05 \pm 2,71$ \\
\hline Измерения & 445 & 464 & 909 \\
\hline Диаметр микрососуда, мкм & $95 \pm 47$ & $89 \pm 56$ & $90 \pm 50$ \\
\hline Измерения & 79 & 171 & 250 \\
\hline Субъекты с альвеолярными флуоресцентными макрофагами & $16^{\#}$ & $1^{\#}$ & 17 \\
\hline $\begin{array}{l}\text { Альвеолы с флуоресцентными макрофагами / общее } \\
\text { количество обследованных альвеол }\end{array}$ & $77 / 85^{\#}$ & $1 / 107^{\#}$ & $78 / 192$ \\
\hline
\end{tabular}

Примечание. Данные представлены как n или среднее \pm среднеквадратическое отклонение, за исключением значений диаметров микрососудов, которые представлены как среднее значение выборки \pm межквартильный размах. ${ }^{\#}-\mathrm{p}<$ 0,0001, тестовый критерий хи-квадрат [8].
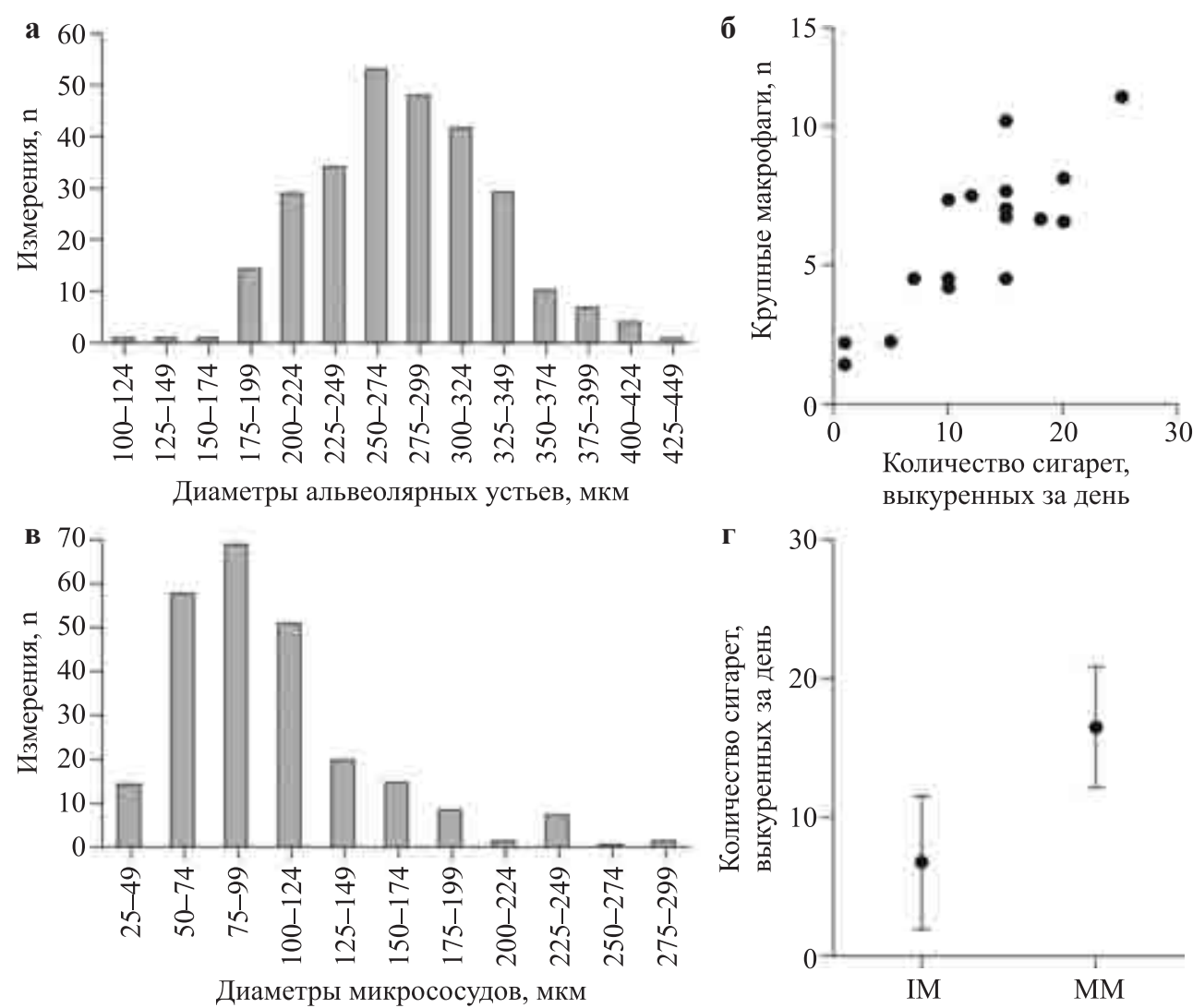

Рис. 8. Внутриацинарная морфометрическая и клеточная оценка в условиях in vivo, выполненная с применением оптоволоконной флуоресцентной конфокальной микроскопии: а и в - распределение альвеолярных устьев и диаметров надальвеолярных капилляров в серии здоровых добровольцев, исследованных методом альвеоскопии; б и г - оценка в условиях in vivo величины альвеолярного макрофага и его мобильности в соответствии с воздействием табака; б крупные макрофаги имели размер $>30$ мкм; $\mathrm{r}=0,77$; $<$ < 0,0002; г - IM: неподвижный макрофаг; ММ: мобильный макрофаг; $\mathrm{p}<0,0001$ [8]

ний, полученных у некурящих (рис. 7). Альвеолярные полости курильщиков, как правило, заполнены клетками с высокой флуоресцентностью, которые соответствуют альвеолярным флуоресцентным макрофагам, присутствие которых является весьма специфичным для активного курения. При использовании FCFM могут быть оценены морфологические маркеры активации альвеолярных макрофагов, такие как их величина, количество и подвижность, которые, как показано, в значительной степени со- 
ответствуют количеству выкуриваемых за день сигарет (рис. 8) [8].

Интенсивность альвеолярной аутофлуоресценции у активных курильщиков проявляется в более значительной степени по сравнению с некурящими и зависит от интенсивности свечения макрофагов в альвеолах. Для активных курильщиков в условиях in situ были выполнены микроспектрометрические измерения альвеол, которые показали, что основной вклад флуорофора в альвеолярный сигнал FCFM соответствует табачной смоле (рис. 4) [8, 21]. В связи с этим у курильщиков часто могут быть получены особо контрастные изображения альвеол (рис. 7).

\section{ПОТЕНЦИААЬНЫЕ ВОЗМОЖНОСТИ ПРИМЕНЕНИЯ И ВОЗМОЖНЫЕ ОГРАНИЧЕНИЯ АЛЯ ОПТОВОАОКОННОЙ ФАУОРЕСЦЕНТНОЙ КОНФОКААЬНОЙ МИКРОСКОПИИ ПРИ ВИЗУААИЗАЦИИ АИСТААЬНОЙ ЧАСТИ АЕГКОГО}

Процедура бронхоальвеолоскопии является первым методом, который позволил получать микроструктурные изображения лобулярной и альвеолярной структуры легких живого человека в режиме реального времени и с высоким разрешением. Таким образом, данная техника, как представляется, имеет большой потенциал для минимально инвазивных исследований дистальной части легкого в условиях in vivo. Для визуализации дистальных частей легкого данная технология может также использоваться в сочетании с современными методами локализации дистальной структуры и отбора проб, например, с электромагнитной навигацией или радиальным ультразвуковым эндобронхиальным исследованием на основе применения минизондов. Потенциально клиническое применение оптоволоконной флуоресцентной конфокальной микроскопии может служить для оценки периферических диффузных заболеваний легкого и диагностики in vivo периферических узелков в легких [17]. Типичные изменения упругих структур при идиопатическом легочном фиброзе и клеточные изображения периферической аденокарциномы показаны на рис. 9.

В то время как предварительные результаты FCFM в обоих этих направлениях выглядят очень обнадеживающими, следует также подчеркнуть потенциальные трудности использования этого метода. Такие трудности связаны в основном с интерпретацией FCFM-изображений и стандартизацией альвеолярной визуализации.

Измененные изображения ацинарных упругих структур, полученные при помощи оптоволоконной флуоресцентной конфокальной микроскопии
(FCFM), могут иметь место и в нормальном легком человека, что объясняется сжатием и изменением хрупкой ацинарной структуры при продвижении зонда. Это связано с режимом проникновения зонда в ацинус, что предполагает нарушение бронхиол и альвеолярных стенок, после чего сжатие влияет на более устойчивые структуры протоков. Минимальное искажение изображения наблюдается в тех случаях, когда зонд применяется по оси канала, в результате чего происходит более подробная визуализация задних планов, чем теоретически обеспечивается глубина фокуса системы в 50 мкм [13]. Этот эффект сжатия может трудно контролироваться в условиях in vivo. В наших силах получать более воспроизводимые результаты, осторожно отводя зонд назад, как только будет получено альвеолярное изображение, и выполняя анализ изображений до потери последнего контакта. Таким образом, будущие исследования должны включать в себя стандартизацию методов эндоскопического исследования.

С другой стороны, FCFM регистрирует исключительно тот сигнал, который поступает от флуоресцентных структур в ответ на возбуждение волнами соответствующей длины. В связи с этим в режиме собственной аутофлуоресценции (т. е. без использования экзогенных флуорофоров) в условиях in vivo у некурящих оптоволоконная флуоресцентная конфокальная микроскопия обеспечивает визуализацию только эластина периферической и осевой соединительной ткани. Данные литературы указывают, что такая информация может быть полезна только для исследования некоторых заболеваний периферических отделов легких [34-36]. Однако, поскольку конфокальная флуоресцентная микроскопия дистальной части легкого, вероятно, будет сильно отличаться от соответствующей гистопатологии, симптоматика при визуализации структуры эластина легкого, выполненной при помощи оптоволоконной флуоресцентной конфокальной микроскопии, должна будет характеризоваться в условиях патологии. В связи с этим, прежде чем будет дана оценка месту оптоволоконной флуоресцентной конфокальной микроскопии при стандартном обследовании периферических отделов легких, обязательно должны быть проведены сравнительные исследования конфокальной альвеолярной визуализации в условиях in vivo для пациентов с болезнями периферических отделов легких и здоровых добровольцев.

До сих пор в конфокальной микроэндоскопии дыхательных путей для визуализации в условиях in vivo клеточной и интерстициальной ткани дыхательных путей и паренхимы дистальных отделов легких использовали только эндогенную аутофлуоресценцию или простые контрастные флуорохромы. В будущем, используя контрастные 

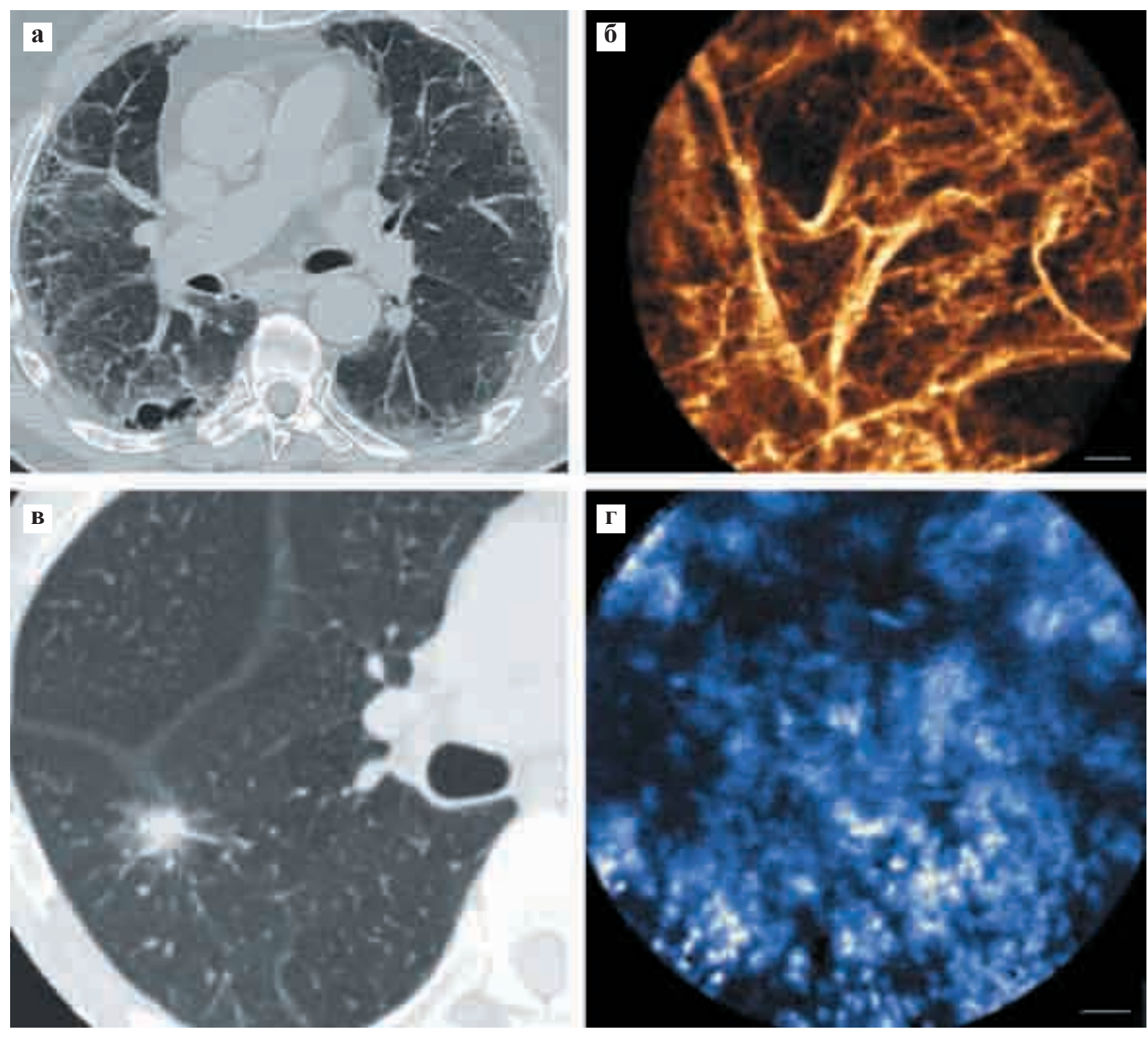

Рис. 9. Визуализация при помощи оптоволоконной флуоресцентной конфокальной микроскопии периферического легкого: а и б - идиопатический легочный фиброз; в и г - узелок периферийного легкого: аденокарцинома; а и в компьютерная томография грудного отдела; б - дистальная FCFM-визуализация язычка (LB5a) (автофлуоресценция FCFM при длине волны возбуждения 488 нм). г - FCFM визуализация периферических узелков представленных в (в). Конфокальный мини-зонд был введен в узелок через внешнюю оболочку с использованием радиального эндобронхиального ультразвукового исследования перед отбором образца (поверхностный метиленовый синий и FCFM при длине волны возбуждения 660 нм). Масштаб: 50 мкм

молекулярные соединения, можно будет расширить применение данного метода на область молекулярной визуализации в условиях in vivo. Недавно были опубликованы результаты экспериментальных исследований, использовавших эту стратегию. В этих работах приведены изображения, полученные при конфокальной микроскопии с молекулярными зондами для диагностики предракового состояния ротовой полости в условиях ex vivo [37] и дисплазии толстой кишки в условиях in vivo [38]. Совместно c FCFM молекулярная визуализация в будущем может обеспечить раннюю диагностику и оценку результатов терапии при многих заболеваниях легких.

\section{СПИСОК АИТЕРАТУРЫ}

1. Kiesslich R., Goetz M., Neurath M.F. Virtual histology // Best Pract Res Clin Gastroenterol. 2008; 22: 883-897.
2. Guillaud M., Richards-Kortum R., Follen M. Paradigm shift: a new breed of pathologist // Gynecol. Oncol. 2007; 107: Suppl. 1, S46-S49.

3. Goetz M., Kiesslich R. Confocal endomicroscopy: in vivo diagnosis of neoplastic lesions of the gastrointestinal tract // Anticancer Res. 2008; 28: 353-360.

4. Goetz M., Kiesslich R., Dienes H.P., Drebber U., Murr E., Hoffman A., Kanzler S., Galle P.R., Delaney P., Neurath M.F. In vivo confocal laser endomicroscopy of the human liver: a novel method for assessing liver microarchitecture in real time // Endoscopy. 2008; 40: 554-562.

5. Kiesslich R., Goetz M., Neurath M.F. Confocal laser endomicroscopy for gastrointestinal diseases // Gastrointest. Endosc. Clin. N Am. 2008; 18: 451-466.

6. Meining A. Confocal endomicroscopy // Gastrointest. Endosc. Clin. N Am. 2009; 19: 629-635.

7. Thiberville L., Moreno-Swirc S., Vercauteren T., Peltier E., Cavé C., Bourg Heckly G. In vivo imaging of the 
bronchial wall microstructure using fibered confocal fluorescence microscopy // Am. J. Respir. Crit. Care Med. 2007; 175: 22-31.

8. Thiberville L., Salaün M., Lachkar S., Dominique S., Moreno-Swirc S., Vever-Bizet C., Bourg-Heckly G. Human in vivo fluorescence microimaging of the alveolar ducts and sacs during bronchoscopy // Eur. Respir. J. 2009; 33: 974-985.

9. St Croix C.M., Leelavanichkul K., Watkins S.C. Intravital fluorescence microscopy in pulmonary research // Adv. Drug. Deliv. Rev. 2006; 58: 834-840.

10. MacAulay C., Lane P., Richards-Kortum R. In vivo pathology: microendoscopy as a new endoscopic imaging modality // Gastrointest. Endosc. Clin. N Am. 2004; 14: 595-620.

11. Boyette L.B., Reardon M.A., Mirelman A.J., Kirkley T.D., Lysiak J.J., Tuttle J.B., Steers W.D. Fiberoptic imaging of cavernous nerves in vivo // J. Urol. 2007; 178: 2694 2700 .

12. Laemmel E., Genet M., Le Goualher G., Perchant A., Le Gargasson J.F., Vicaut E. Fibered confocal fluorescence microscopy (CellviZio) facilitates extended imaging in the field of microcirculation. A comparison with intravital microscopy // J. Vasc. Res. 2004; 41: 400-411.

13. Vincent P., Maskos U., Charvet I., Bourgeais L., Stoppini L., Leresche N., Changeux J.P., Lambert R., Meda P., Paupardin-Tritsch $D$. Live imaging of neural structure and function by fibred fluorescence microscopy // EMBO Rep. 2006; 7: 1154-1161.

14. Hoffman A., Goetz M., Vieth M., Galle P.R., Neurath M.F., Kiesslich R. Confocal laser endomicroscopy: technical status and current indications // Endoscopy. 2006; 38: 1275-1283.

15. Kiesslich R., Goetz M., Vieth M., Galle P.R., Neurath M.F. Confocal laser endomicroscopy // Gastrointest. Endosc. Clin. N Am. 2005; 15: 715-731.

16. Peng Q., Brown S.B., Moan J., Nesland J.M., Wainwright M., Griffiths J., Dixon B., Cruse-Sawyer J., Vernon $D$. Biodistribution of a methylene blue derivative in tumor and normal tissues of rats // J. Photochem. Photobiol. B. 1993; 20: 63-71.

17. Thiberville L., Salaün M., Lachkar S., Dominique S., Moreno-Swirc S., Vever-Bizet C., Bourg-Heckly G. In vivo confocal endomicroscopy of peripheral lung nodules using $488 \mathrm{~nm} / 660 \mathrm{~nm}$ induced fluorescence and topical methylene blue // Eur. Respir. J. 2008; 32: Suppl. 52, 263s.

18. Thiberville L., Salaün M., Moreno-Swirc S. In vivo endoscopic microimaging of the bronchial epithelial layer using $660 \mathrm{~nm}$ fibered confocal fluorescence microscopy and topical methylene blue // Eur. Respir. J. 2007; 30: Suppl. 51, 712s.

19. Gabrecht T., Andrejevic-Blant S., Wagnieres G. Blue-violet excited autofluorescence spectroscopy and imaging of normal and cancerous human bronchial tissue after formalin fixation // Photochem. Photobiol. 2007; 83: 450-458.

20. Richards-Kortum R., Sevick-Muraca E. Quantitative optical spectroscopy for tissue diagnosis // Annu Rev. Phys. Chem. 1996; 47: 555-606.
21. Bourg-Heckly G., Thiberville L., Vever-Bizet C. In vivo endoscopic autofluorescence microspectro-imaging of bronchi and alveoli // Proc SPIE. 2008; 6851.

22. Qu J., MacAulay C., Lam S. Laser-induced fluorescence spectroscopy at endoscopy: tissue optics, Monte Carlo modeling and in vivo measurements // Opt. Eng. 1995; 34: 3334-3343.

23. Lane P.M., Lam S., McWilliams A., Leriche J.C., Anderson M.W., Macaulay C.E. Confocal uorescence microendoscopy of bronchial epithelium // J. Biomed. Opt. 2009; 14: 024008.

24. Jean F., Bourg-Heckly G., Viellerobe B. Fibered confocal spectroscopy and multicolor imaging system for in vivo fluorescence analysis // Opt. Express. 2007; 15: 4008 4017.

25. Becker V., von Delius S., Bajbouj M., Karagianni A., Schmid R.M., Meining A. Intravenous application of fluorescein for confocal laser scanning microscopy: evaluation of contrast dynamics and image quality with increasing injection-to-imaging time // Gastrointest Endosc. 2008; 68: 319-323.

26. Kiesslich R., Fritsch J., Holtmann M., Koehler H.H., Stolte M., Kanzler S., Nafe B., Jung M., Galle P.R., Neurath M.F. Methylene blue-aided chromoendoscopy for the detection of intraepithelial neoplasia and colon cancer in ulcerative colitis // Gastroenterology. 2003; 124: 880-888.

27. Taghavi S.A., Membari M.E., Eshraghian A., Dehghani S.M., Hamidpour L., Khademalhoseini F. Comparison of chromoendoscopy and conventional endoscopy in the detection of premalignant gastric lesions // Can. J. Gastroenterol. 2009; 23: 105-108.

28. Marion J.F., Waye J.D., Present D.H., Israel Y., Bodian C., Harpaz N., Chapman M., Itzkowitz S., Steinlauf A.F., Abreu M.T., Ullman T.A., Aisenberg J., Mayer L. Chromoendoscopy-targeted biopsies are superior to standard colonoscopic surveillance for detecting dysplasia in inflammatory bowel disease patients: a prospective endoscopic trial // Am. J. Gastroenterol. 2008; 103: 2342-2349.

29. Inoue H., Kazawa T., Sato Y., Satodate H., Sasajima K., Kudo S.E., Shiokawa A. In vivo observation of living cancer cells in the esophagus, stomach, and colon using catheter-type contact endoscope, "Endo-Cytoscopy system” // Gastrointest. Endosc. Clin. N Am. 2004; 14: 589594.

30. Shibuya K., Fujiwara T., Yasufuku K., Alaa M., Chiyo M., Nakajima T., Hoshino H., Hiroshima K., Nakatani Y., Yoshino I. Endo-cytoscopy system is a novel endoscopic technology to visualize microscopic imaging of the tracheobronchial tree // Eur. Respir. J. 2008; 32: Suppl. 52, $263 \mathrm{~s}$.

31. Mercer R.R., Crapo J.D. Spatial distribution of collagen and elastin fibers in the lungs // J. Appl. Physiol. 1990; 69: 756-765.

32. Weibel E.R., Sapoval B., Filoche M. Design of peripheral airways for efficient gas exchange // Respir. Physiol. Neurobiol. 2005; 148: 3-21.

33. Weibel E.R., Hsia C.C., Ochs M. How much is there really? Why stereology is essential in lung morphometry // J. Appl. Physiol. 2007; 102: 459-467. 
34. Black P.N., Ching P.S., Beaumont B., Ranasinghe S., Taylor G., Merrilees M.J. Changes in elastic fibres in the small airways and alveoli in COPD // Eur. Respir. J. 2008; 31: 998-1004.

35. Honda T., Ota H., Arai K., Hayama M., Fujimoto K., Yamazaki Y., Haniuda M. Three-dimensional analysis of alveolar structure in usual interstitial pneumonia // Virchows Arch. 2002; 441: 47-52.

36. Honda T., Ota H., Sano K. et al. Alveolar shrinkage in bronchioloalveolar carcinoma without central fibrosis // Lung Cancer. 2002; 36: 283-288.
37. Hsu E.R., Gillenwater A.M., Hasan M.Q., Williams M.D., El-Naggar A.K., Richards-Kortum R.R. Real-time detection of epidermal growth factor receptor expression in fresh oral cavity biopsies using a molecular-specific contrast agent // Int. J. Cancer. 2006; 118: 3062-3071.

38. Hsiung P.L., Hardy J., Friedland S., Soetikno R., Du C.B., Wu A.P., Sahbaie P., Crawford J.M., Lowe A.W., Contag C.H., Wang T.D. Detection of colonic dysplasia in vivo using a targeted heptapeptide and confocal microendoscopy // Nat. Med. 2008; 14: 454-458. 